Elsevier required licence: (c) $<2018>$. This manuscript version is made available under the CC-BY-NC-ND 4.0 license http://creativecommons.org/licenses/bync-nd/4.0/ 


\title{
Bioprocessing for elimination antibiotics and hormones from swine wastewater
}

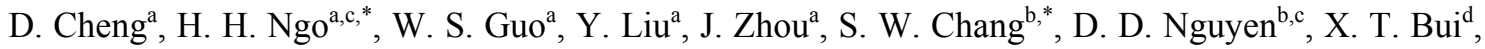 \\ X. B. Zhang ${ }^{\mathrm{a}}$ \\ ${ }^{a}$ Joint Research Centre for Protective Infrastructure Technology and Environmental Green Bioprocess, School \\ of Civil and Environmental Engineering, University of Technology Sydney, Ultimo NSW 2007, Australia and \\ Department of Environmental and Municipal Engineering, Tianjin Chengjian University, Tianjin 300384, China \\ ${ }^{b}$ Department of Environmental Energy \& Engineering, Kyonggi University, 442-760, Republic of Korea \\ ${ }^{c}$ Institution of Research and Development, Duy Tan University, Da Nang, Vietnam \\ ${ }^{d}$ Faculty of Environment and Natural Resources, University of Technology, Vietnam National University-Ho \\ Chi Minh, District 10, Ho Chi Minh City Vietnam \\ * Corresponding authors: E-mail address: ngohuuhao121@gmail.com or h.ngo@uts.edu.au (H. H. Ngo); \\ swchang@kyonggi.ac.kr (S.W. Chang)
}

\section{Abstract}

Antibiotics and hormones in swine wastewater have become a critical concern worldwide due to the severe threats to human health and the eco-environment. Removal of most detectable antibiotics and hormones, such as sulfonamides (SAs), SMs, tetracyclines (TCs), macrolides, and estrogenic hormones from swine wastewater utilizing various biological processes were summarized and compared. In biological processes, biosorption and biodegradation are the two major removal mechanisms for antibiotics and hormones. The residuals in treated effluents and sludge of conventional activated sludge and anaerobic digestion processes can still pose risks to the surrounding environment, and the anaerobic processes' removal efficiencies were inferior to those of aerobic processes. In contrast, membrane bioreactors (MBRs), constructed wetlands (CWs) and modified processes performed better because of their higher biodegradation of toxicants. Process modification on activated sludge, anaerobic digestion and conventional MBRs could also enhance the performance (e.g. removing up to 98\% SMs, $88.9 \% \mathrm{TCs}$, and $99.6 \%$ hormones from wastewater). The hybrid process combining MBRs with biological or physical technology also led to better removal efficiency. As such, modified conventional biological processes, advanced biological technologies and 
MBR hybrid systems are considered as a promising technology for removing toxicants from swine wastewater.

34 Keywords: Swine wastewater, bioprocesses, antibiotics, hormones, removal efficiency

\section{Abbreviations}

37 SAs, sulphonamides; SMZ, sulfamethazine; SMX, sulfamethoxazole; SD, sulfadiazine; 38 SMM, sulfamonomethoxine; TCs, tetracyclines; TC, tetracycline; OTC, oxytetracycline; 39 CTC, chlortetracycline; DC, doxycycline; E1, estrone; E2, 17ß-estradiol; EE2, 17 $\alpha$ 40 ethinylestradiol; ARGs, antibiotic resistant genes; (tetO, ttetC, tetM, tetW, tetA, tetX), 41 tetracycline resistance genes; (sulI, sulII, sulIII), sulfonamide resistance genes; BOD, 42 biological oxygen demand; $\mathrm{COD}$, chemical oxygen demand; $\mathrm{NH}_{3}-\mathrm{N}$, ammonia nitrogen; TN, 43 total nitrogen; TP, total phosphorous; TSS, total suspended solids; HRT, hydraulic retention 44 time; SRT, sludge retention time; MBRs, membrane bioreactors; CWs, constructed wetlands; 45 SF-CWs, free water surface constructed wetlands; HSSF-CWs, horizontal subsurface flow constructed wetlands; VSSF-CWs, vertical subsurface flow constructed wetlands; CAS,

47 conventional activated sludge; $\mathrm{AD}$, anaerobic digestion; SBR, sequencing batch reactor; $\mathrm{A} / \mathrm{O}$ process, anaerobic/oxic process; $\mathrm{A}^{2} \mathrm{O}$, anaerobic-anoxic-oxic process; UASB, up-flow anaerobic sludge blanket; ASBR, anaerobic sequencing batch reactor; CSTR, continuously 50 stirred tank reactor; BAF, biological aerated filter; BF-MBR, biofilm MBR; AFMBR, 51 anaerobic fluidized membrane bioreactor; AnMBR, anaerobic membrane bioreactor; GAC, 52 granular activated carbon; PAC, powder activated carbon; USDA: United States Department 53 of Agriculture.

\section{Introduction}

The world's accelerating population means that meat consumption has risen in people's

56 diets; pork as one of the most popular meats in the world now accounts for about $38 \%$ of 
57 meat production worldwide. The USDA reported in the 'Livestock and Poultry: World 58 Markets and Trade' that in the past five years the annual average consumption of pork was up 59 to $1.1 \times 10^{8}$ tons. With the demand for pork being so large, conventional small pig farms are 60 expanding rapidly into intensive large pig farms, resulting in more and more swine 61 wastewater being discharged from pig farms. It is reported that more than 460 million tons of 62 swine wastewater were generated in 2011 in China (Liu et al., 2016). As the global demand 63 for pork increases consistently, the amount of swine wastewater will keep increasing in the 64 future (Lim, 2008).

65 It is widely known that swine wastewater contains much organic matter, solids, volatile,

66 faecal coliforms and nutrients with high chemical oxygen demand (COD) of 3000-15,000

$67 \mathrm{mg} / \mathrm{L}$, ammonia nitrogen $\left(\mathrm{NH}_{3}-\mathrm{N}\right)$ of $400-1400 \mathrm{mg} / \mathrm{L}$, total nitrogen $(\mathrm{TN})$ of $600-2100 \mathrm{mg} / \mathrm{L}$ 68 and total phosphorous (TP) of $100-250 \mathrm{mg} / \mathrm{L}$. Since the early $1950 \mathrm{~s}$, a variety of drugs and 69 feed additives have been used in livestock farming to treat infections, and improve growth 70 and feed efficiency worldwide (Sarmah et al., 2006b). According to one report, 71 approximately $88 \%$ of growing pigs in the U.S. receive antibiotics in their feed to prevent 72 disease and promote growth. The U.S. Food and Drug Administration reported that about 7329.9 million pounds of antibiotics were used on farm animals (Leavey-Roback et al., 2016; 74 Wang \& Wang, 2016). Similarly, in Vietnam, more than 11 million pounds of antibiotics 75 were used for growth promotion, 25 million pounds for disease prevention, and 37 million 76 pounds for therapeutic purposes in swine farming. China the world's top pork consumption 77 country used approximately 6000 tons of veterinary antibiotics every year (Chen et al., 2010; 78 et al., 2010).

79 However, both antibiotics and hormones are poorly absorbed by pigs, and most of them 80 are not completely metabolized; about $70 \%-90 \%$ are excreted through faeces and urine in 81 unchanged forms or as metabolites (Massé et al., 2014). Thus, the swine waste is a significant 
82 source of antibiotics and hormones in the environment. As reported elsewhere, the 83 normalized daily excretion mass of antibiotics from a swine was estimated about $18.2 \mathrm{mg} / \mathrm{d}$ 84 in China in 2010 (Zhou et al., 2011). In 2004 - 2014, the total excretion mass of estrogenic 85 hormones was in the range of 0.12 to $2.3 \mathrm{mg} / \mathrm{d}$ per pig mainly through urine (98-99\%), which 86 is at least ten times higher than a human (Johnson et al., 2006; Lange et al., 2002; Zhang et al., 87 2014). Besides high amounts of suspended solids, organic matter, nitrogen and phosphorus, 88 swine wastewater also contains appreciable amounts of antibiotics and hormones. Generally, 89 the major and most common antibiotics in swine wastewater are tetracyclines (TCs), 90 sulfonamides (SAs), and macrolides, while hormones usually take the form of estrogens, 91 androgens, glucocorticoids and progestogens (Aad et al., 2012). Among these toxicants, due 92 to their large concentration, tetracyclines (TCs) and sulfonamides (SAs) are the most 93 frequently reported antibiotics in swine wastewater (Shi et al., 2013), while estrone (E1), 94 17 3 -estradiol (E2), and synthetic 17 $\alpha$-ethinylestradiol (EE2) are the most studied family of 95 estrogenic hormones. This is because of their severe environmental impact, even at very low 96 concentrations (0.1 - 0.5 ng/L) (Adeel et al., 2017). Previous studies' results have shown that 97 the concentrations of the above mentioned antibiotics and hormones in swine wastewater 98 varied with sampling locations and analysis methods applied (Table 1). 
Concentrations of target antibiotics and hormones in swine wastewater

\begin{tabular}{|c|c|c|c|c|c|}
\hline \multirow[b]{2}{*}{ Classes } & \multirow[b]{2}{*}{ Compounds } & \multicolumn{2}{|r|}{ Concentrations } & \multirow{2}{*}{ Analysis methods ${ }^{\mathrm{a}}$} & \multirow[b]{2}{*}{ Reference } \\
\hline & & Locations & $(\mu \mathrm{g} / \mathrm{L})$ & & \\
\hline \multirow{11}{*}{ Sulfonamides } & Sulfonamides & South China & $8.59 \times 10^{-3}-1.59$ & LC-MS/MS & (Shi et al., 2013) \\
\hline & (SAs) & Malaysian & $5.03 \times 10^{-3}-0.95$ & / & (Malintan \& Mohd, 2006) \\
\hline & & Beijing, China & $0.44-324.40$ & & Wang et al., 2016; Ben et \\
\hline & & & & LC-MS & al., 2008; Pan et al., 2011) \\
\hline & Sulfamethazine & Jiangsu, China & ND-63.60 & HPLC-MS/MS & (Wei et al., 2011) \\
\hline & $(\mathrm{SMZ})$ & Shandong, China & 14.56 & / & (Ben et al., 2013) \\
\hline & & Bayer, Germany & $18.50-19.20$ & LC-MS/MS & (Heuer et al., 2008) \\
\hline & & Germany & 49.50 & LC-IT-ToF/MS & (Kim et al., 2013) \\
\hline & Sulfamethoxazole & & & & (Ben et al., 2008; Pan et al., \\
\hline & $(\mathrm{SMX})$ & Berjing, C nina & $14.05-510.50$ & LC-NIS & 2011) \\
\hline & Sulfadiazine(SD) & East China & 98.90 & HPLC-MS/MS & (Chen et al., 2012b) \\
\hline
\end{tabular}




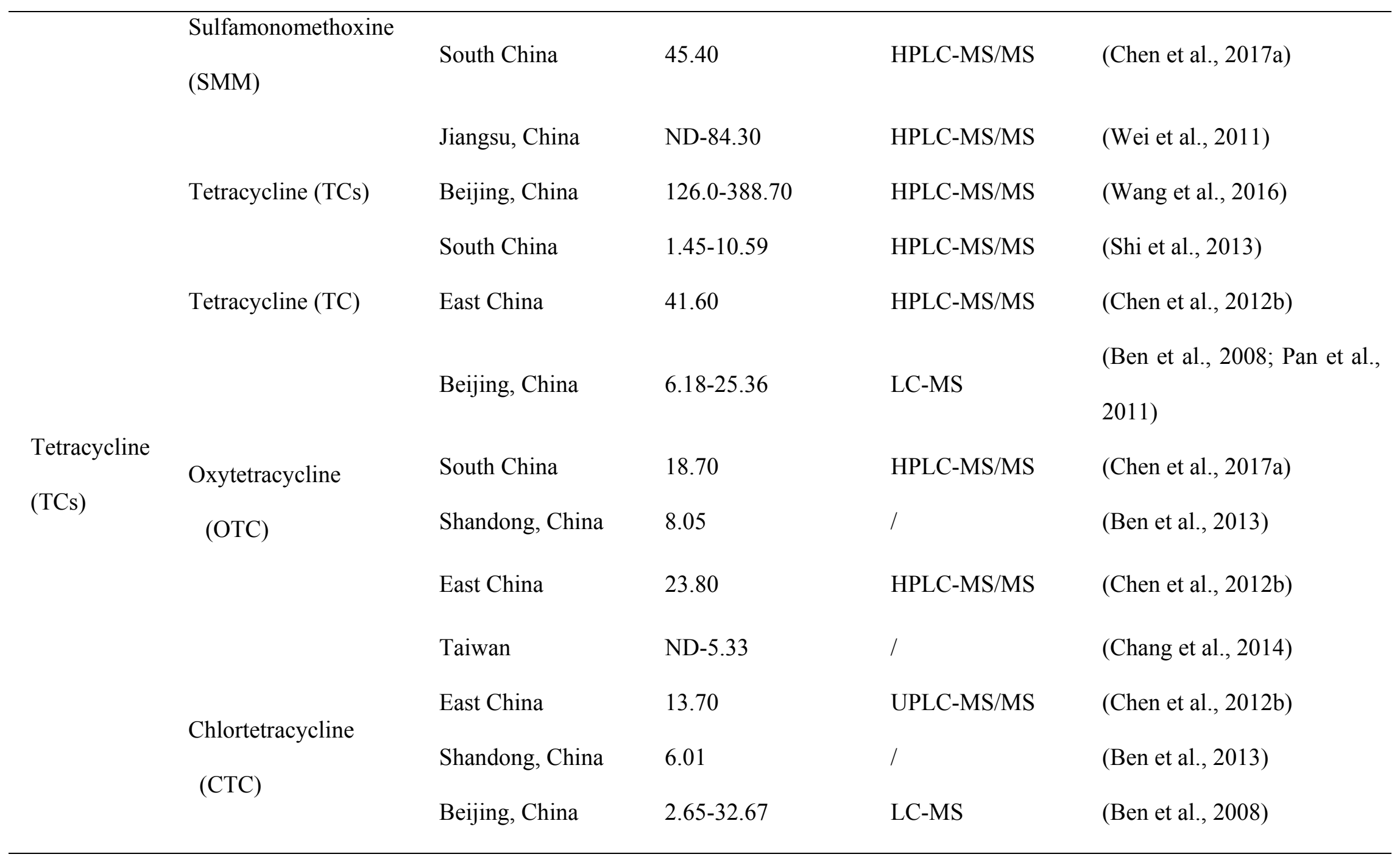




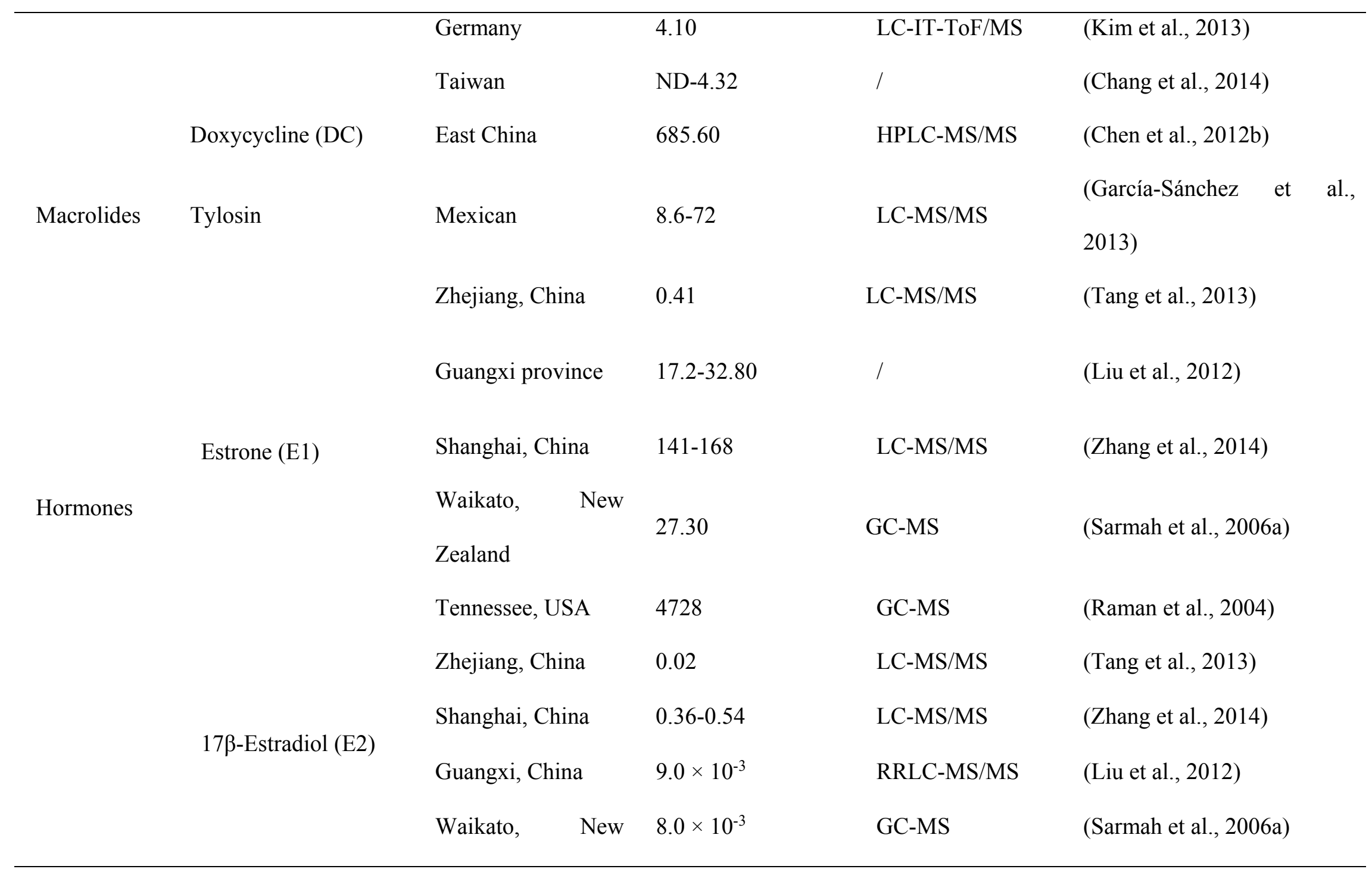




\section{Zealand}

$17 \alpha$-Ethynylestradiol

$\begin{array}{lllll} & \text { Guangxi, China } & 0.18-0.36 & \text { RRLC-MS/MS } & \text { (Liu et al., 2012) } \\ \text { Progestogens } & \text { Guangdong, China } & 20.20 & \text { HPLC-MS/MS } & \text { (Liu et al., 2015a) }\end{array}$

101 a LC-MS/MS: liquid chromatography-tandem mass spectrometry; HPLC-MS/MS: high performance liquid chromatography and tandem mass spectrometry; LC-IT-ToF/MS: liquid chromatography-ion-trap mass spectrometer (IT-MS)-time-of-flight mass spectrometer in series; GCMS:

RRLC-MS/MS:

rapid

resolution

liquid

chromatography-tandem

mass

spectrum. 
However, the extensively used wastewater treatment plants designed to remove routine pollutants like nitrogen and phosphorus in livestock farms often do not completely remove 106 antibiotics and hormones. Residual antibiotics and hormones are continuously discharged 107 from livestock waste treatment plants and end up in aquatic environments (Ebele et al., 2017). 108 Additionally, due to the predominance of organic agricultural practices in most developing 109 and some developed countries, swine wastes widely used as fertilizers are considered to be 110 significant sources of these environmental pollutants (Speltini et al., 2011). Several studies 111 have reported the detection of antibiotics and hormones in surface waters, ground waters and 112 soils nearby swine farms, and the maximum concentrations of TCs and SMs were up to 250 $113 \mu \mathrm{g} / \mathrm{L}$ in water and $170 \mu \mathrm{g} / \mathrm{kg}$ in soil, respectively (Campagnolo et al., 2002; Chen et al., 114 2012a; Koike et al., 2007; Peak et al., 2007). Trace level residual hormones in nearby surface 115 waters and vegetable fields still can pose potential risks to aquatic organisms, such as fish in 116 receiving aquatic environments (Liu et al., 2015a). Thus, resulting from the incomplete 117 removal during on-farm wastewater treatment, swine wastewater has become a major source 118 of antibiotics and hormones pollution, and their major transport pathways are summarized in 119 Figure 1. 


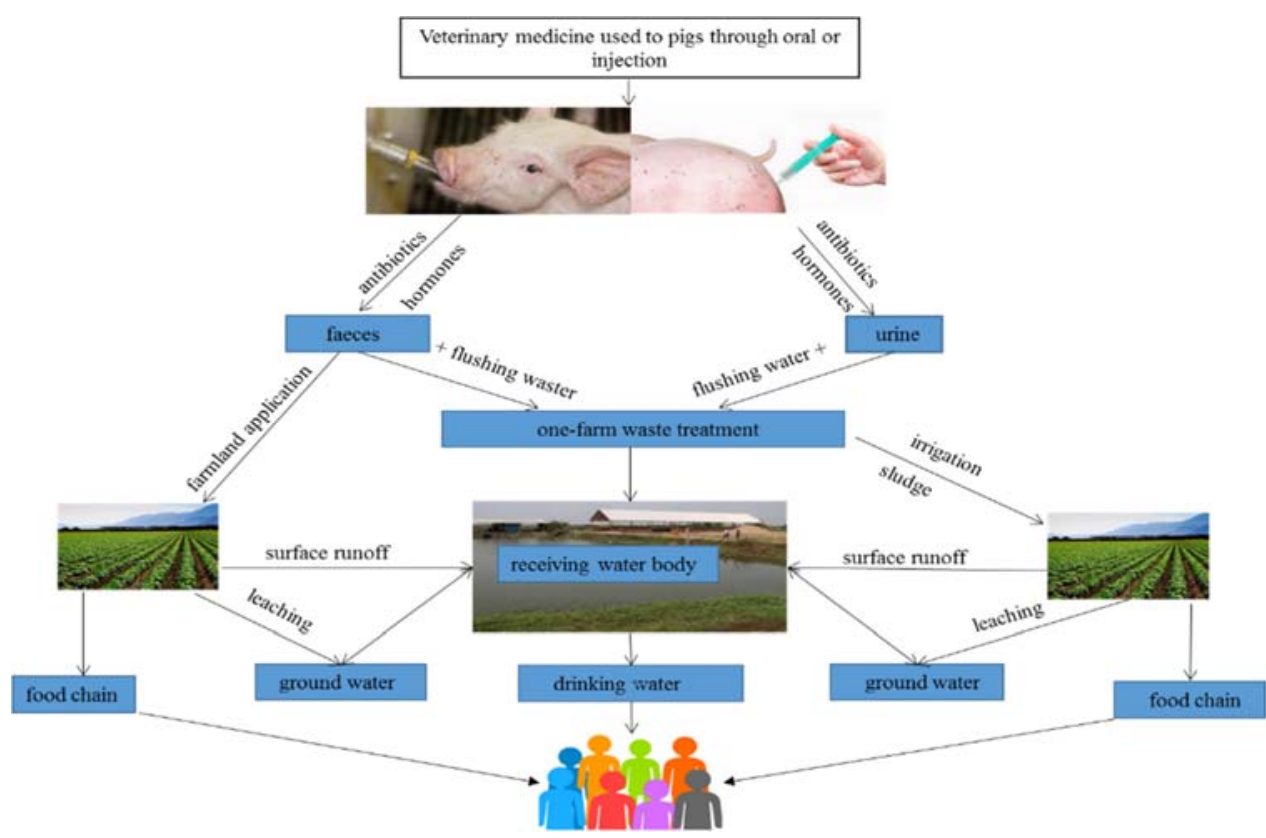

nd Fig.1.

Fig.1 Transport pathways of antibiotics a hormones from swine farm to environment

It is widely known that the occurrence and residues of the above antibiotics and hormones pose serious threats to human health and the eco-environment, because they could generate antibiotic resistant bacteria and antibiotic resistant genes (ARGs), and endocrine disrupting effects in the environment (Adeel et al., 2017; Gonzalez Ronquillo \& Angeles Hernandez, 2017). Eco-toxicity studies demonstrated that such pollutants could affect the growth, reproduction and behavior of birds, fishes, invertebrates, plants and bacteria, even at levels as low as a few ng/L (de Cazes et al., 2014a). In recent years, due to the use of antibiotics and hormones in swine farms, ARGs were frequently detected in swine wastewater (Combalbert et al., 2012; Sui et al., 2016). For example, He et al. (2016) showed ARGs in swine wastewater samples were at least 31 times higher than in well water and fishpond water. Furthermore, through direct discharge and farmland application of swine wastewater, antibiotics and ARGs were very evident in adjacent swine farms (Ben et al., 2017; Gao et al., 2012; Hsu et al., 2014; Munir et al., 2011). Ben et al. (2017) investigated the ARGs' encoding resistance to sulfonamide and tetracycline antibiotics in nine swine feedlots located in China's Shandong Province. Results indicated that the target ARGs were widely 
137 distributed in swine wastes, with mean relative abundances ranging from $3.3 \times 10^{-5}$ (tetC) to $1385.2 \times 10^{-1}\left(\right.$ tetO) in swine manure and from $7.3 \times 10^{-3}\left(\right.$ tetC) to $1.7 \times 10^{-1}($ tetO) in swine 139 wastewater. Through farmland application and the discharge of swine wastewater, such 140 ARGs were disseminated to the adjacent environments, resulting in mean relative abundances 141 ranging from $9.9 \times 10^{-5}\left(\right.$ tetW) to $1.1 \times 10^{-2}\left(\right.$ tetO) in soils and from $3.1 \times 10^{-4}($ tetW) to $1.1 \times$ $14210^{-2}$ (sul II ) in receiving river sediments. These definitely will pose potential risks to food safety and people's health (Becerra-Castro et al., 2015). As bioactive hazardous substances, 144 antibiotics in soil also influence bacteria and other organisms in nearby soil environments 145 (Baguer et al., 2000). It has been reported that antibiotics in soil can alter soil microbial 146 constitution and function by killing the essential microbes needed for supplying nutrients to the plants and leading to imbalance in microbial population due to the resistant selection of particular species. It can also increase the occurrence and abundance of ARGs in various soil bacteria (Tasho \& Cho, 2016). Numerous reports indicated that antibiotics in soil disturbed the healthy growth of plants resulting in stunted crops, decreased yield and unsafe food issues. When farmland is fertilized by pig slurry containing veterinary antibiotics, the root growth and seed germination of plants will be affected and result in the plants containing different levels of antibiotics (Du \& Liu, 2012; Migliore et al., 2003).

Besides direct discharge of swine wastewater into the aquatic environment, the relative hydrophilicity of the antibiotics also makes it easy for them to enter aquatic environments through surface runoff and leaching. Once antibiotics are excreted and enter aquatic 157 environments, they can increase antibiotic resistance in aquatic microorganisms. It is reported 158 that residual OTC inhibits immunological functioning and drug resistance in fish, shrimp, and 159 shellfish and threatens human health through bioaccumulation (Uno et al., 2006). Yao et al. (2017) studied the occurrence of 14 antibiotics (fluoroquinolones, tetracyclines, macrolides and sulfonamides) in groundwater and surface water at Jianghan Plain - an alluvial plain 
situated in the middle and south of Hubei, China - during three seasons. Their results indicated that the measured antibiotics in both surface water and groundwater posed a significant risk to algae growth.

In contrast to antibiotics, hormones can cause significant biological responses at very low concentrations, as they have serious long-term impacts on the health of wildlife and humans (Adeel et al., 2017). Adeel et al. (2017) further indicated estrogenic hormones at pollutant levels could affect healthy growth of plants and reproductive development of animals, and even could cause breast cancer in women and prostate cancer in men. For example, at a few ng/L levels, E1 and E2 can affect the normal sexual development of some aquatic species and potentially cause yet unknown effects on ecosystems, and E2 can reduce sperm fertility drastically and induce vitellogenin in male trout at about $1 \mathrm{ng} / \mathrm{L}$ (Lahnsteiner et al., 2006). According to the MSNBC report published in 2004, three Colorado Rivers had $50 \%$ of male fish with both male and female characteristics dominant. Deksissa (2008) pointed out the presence of testosterone and its metabolite androstenedione in aquatic ecosystems was linked to the masculinization of female mosquito fish.

Therefore, antibiotics and hormones pollution has become a major global problem and generated adverse effects on the eco-environment and human health, once they are discharged into soil, surface water, ground water and drinking water. To date, government legislation concerning their discharge and disposition has not been issued, although their use as animal growth promoters has been banned in some countries (Castanon, 2007; Tong et al., 2009; Zheng et al., 2017). What is worse, in some developing countries, for example, China which is the biggest breeder of pigs in the world, some pig farms are equipped only with simple facilities such as anaerobic lagoons and digesters to treat swine wastes, while some just directly discharge the waste into the environment without any treatment (Chen et al., 2017a). Research on different ways to remove them from wastewater before final release into 
the environment has been carried out by scientists worldwide, especially in recent times. Advanced oxidation technology, like chlorine, ultraviolet light and ozone processes have been developed and revealed their effectiveness in removing antibiotics from swine wastewater (Ben et al., 2009; Ben et al., 2011; Qiang et al., 2006). However, such processes not only required large amounts of energy, but also produced some by-products, which can cause secondary pollution to the environment. By contrast, biological treatments are much more popular to treat swine wastewater, and because they are inexpensive and simple to operate, there is no secondary pollution and therefore ecologically clean (Liu et al., 2009).

To date, published review articles related to swine wastewater treatment only focused on the removal of traditional organisms and nutrients from swine wastewater. (Li et al., 2016; Meng et al., 2015). In recent years, considering the high risk of antibiotics and hormones, and the fact that swine wastewater was the hotspot of such toxicants, researchers started investigating their removal during swine wastewater treatment processes (Ben et al., 2017; Chen et al., 2017a; Huang et al., 2017; Tran et al., 2016; Zheng et al., 2017). Till now, this review is the first comprehensive review on the removal of antibiotics and hormones from swine wastewater through biological treatment processes. In this review, we classify biological processes into conventional and promising processes, with a discussion of their removal mechanisms, removal efficiency, influencing factors as well as the fate of antibiotics and hormones during biological treatment processes. Finally, we compare the performance of different bioprocesses for removing antibiotics and hormones from swine wastewater, and discover better approaches for treating such toxicants from swine wastewater.

\section{Removal mechanisms of antibiotics and hormones during bioprocessing}

Previous researches have reported that during biological treatment processes, sorption and biodegradation are two of the most important removal mechanisms of antibiotics and hormones from wastewater, while volatilization and photo-degradation can be ignored (Chen 
212 et al., 2017a; Liu et al., 2015b; Luo et al., 2014; Tiwari et al., 2016; Zheng et al., 2017). Their

213 removal from wastewater treatment processes is affected by various factors, including

214 physicochemical properties of antibiotics and hormones, and operational parameters of

215 wastewater, such as biomass concentration, sludge retention time, hydraulic retention time,

216 temperature and pH (Luo et al., 2014; Tiwari et al., 2017; Wang \& Wang, 2016).

\section{$217 \quad 2.1$ Removal by biosorption}

Biosorption plays a primary role in the removal of toxicants during biological treatment processes. The biosorption mechanism of antibiotics and hormones from aqueous phase to sludge flocs or soils mainly occurs via absorption and adsorption. Absorption occurs due to the hydrophobic interaction of the aliphatic and aromatic group, lipid molecules of sludge or cell membrane of microorganisms, while adsorption occurs due to electrostatic interaction of a positively charged compound to negatively charged microbes and sludge (Li \& Zhang, 2010; Luo et al., 2014). SMs, one of the major antibiotics in swine wastewater, is characterized by easy migration and high bio-toxicity compared to other veterinary antibiotics. Their behaviour in wastewater has been the subject of several analyses (Baquero et al., 2008; Ben et al., 2014; Chen et al., 2012b; Xian et al., 2010). SMs dissolve relatively well in water with low logKow (0.19-0.89), and their biosorption removal from wastewater is expected to have a low potential for hydrophobic partitioning.

As well, in an aqueous solution, SMs can exist in positive, neutral, and negative forms since their speciation would change with $\mathrm{pH}$ value, for example SMX ( $\mathrm{pKa} 1=1.85$, $\left.\mathrm{pKa}_{2}=5.60\right)$, as the $\mathrm{pH}$ value is between $\mathrm{pKa}_{1}$ and $\mathrm{pKa}_{2}, \mathrm{SMX}$ is present predominantly as a neutral species, but as the $\mathrm{pH}$ value $>\mathrm{pKa}_{2}$, it would become a negatively charged species.

234 Since the surface charge of the sludge is predominantly negative within the $\mathrm{pH}$ range of 3.0interaction with the negatively charged surface of the activated sludge (Kara et al., 2008). 
237 This has been confirmed by the research of Abegglen et al. (2009), Yang et al. (2011), and 238 Yang et al. (2012), they concluded that SMs were little adsorbed onto sludge. Similarly, Ben 239 et al. (2014) assessed the adsorption behavior of SMs in activated sludge from swine 240 wastewater, and discovered that only about $5 \%$ of SMN was adsorbed on the activated sludge 241 when it reached equilibrium after 6 hrs. Zhou et al. (2011) also drew a similar conclusion that 242 a large proportion of SMN was found in effluents while only a small ratio was found in the 243 sludge after treatment by activated sludge processes. Yang et al. (2011) confirmed the 244 adsorption and desorption of SMs on activated sludge achieved equilibrium in the first few 245 contact hours. The adsorption/desorption isotherms were well described by the Freundlich 246 isotherm.

247 In contrast, biosorption removal of TCs from swine wastewater may play a considerable 248 role in their overall removal, in spite of their negative logKow. Lou et al. (2017) indicated 249 TCs were highly adsorbed by suspended organic matters in swine wastewater through 250 hydrogen-bonding and cation-exchange in acid conditions, and electrostatic repulsion in 251 neutral or alkaline conditions. Similarly, TCs are easily adsorbed on activated sludge. The 252 biosorption mechanisms of TCs onto activated sludge contribute to electrostatic interactions 253 between the positive charges of zwitterion species of TCs and the negatively charged surface 254 of activated sludge (Prado et al., 2009a). Studies indicated that biosorption mechanisms 255 played important roles in the removal of TCs from aqueous phase during the treatment, 256 because high proportions of TCs were found in the sludge (Sarmah et al., 2006b), one study 257 on removing TC from swine wastewater also reported similar results (Wei et al., 2014). 258 Additionally, the adsorption of TCs by active sludge could be well explained by Langmuir 259 isotherm model (Li \& Zhang, 2016; Mihciokur \& Oguz, 2016; Prado et al., 2009a). Li and 260 Zhang (2016) indicated that a pseudo-second-order model could successfully describe 261 adsorption and desorption kinetics of TC and OTC on activated sludge. 

hydrophobic properties and could partially adsorb onto the solid phase (Clara et al., 2004; Silva et al., 2012). Yamamoto et al. (2003) carried out a series of biosorption experiments to determine the minimal equilibrium time between water and solid phases of estrone (E1), 17 $\beta$ estradiol (E2), and 17 $\alpha$-ethinylestradiol (EE2). Their results revealed that $87-97 \%$ of the hormones were linked to sludge particles within half an hour, and after 2 hrs the equilibrium was approached. Furthermore, Zheng et al. (2016) reported that acidic conditions were found to be particularly conducive to their adsorption processes, since hydrogen bonding occurred between carboxylic groups on the surface of the sludge and hydroxyl groups of hormones at lower $\mathrm{pH}$. This is consistent with the physicochemical character $(\mathrm{pKa}>10)$ of estrogenic hormones. Meanwhile, Zheng et al. (2016), Ren et al. (2007) and Banihashemi and Droste (2014) concluded that Freundlich sorption isotherm could more realistically describe the adsorption process of E1, E2, E3 and EE2 than the Langmuir isotherm, and from the perspective of adsorption kinetics (intra-particle diffusion, first-order kinetics, pseudo-firstorder kinetics, and pseudo-second-order kinetics), the adsorption of E2 onto active sludge could be best explained by the pseudo-second-order kinetic model.

\subsection{Removal by biodegradation}

Biodegradation is the process whereby microorganisms decompose organic pollutants. It represents the most important mechanism for removing antibiotics and hormones from swine wastewater (Chen et al., 2012b; Luo et al., 2011; Tijani et al., 2013; Zheng et al., 2017). For example, Zheng et al. (2017) demonstrated that more than $60 \%$ of 11 veterinary antibiotics in swine wastewater were removed by biodegradation while only $24 \%$ were adsorbed by sludge in a lab-scale intermittently aerated sequencing batch reactor, especially for SMs, whose removal almost by biodegradation $(96.2 \%)$ in the reactor. According to a recent study by 
and anaerobic conditions whilst biodegradation played a more dominant role than biosorption The author also demonstrated the removal of these antibiotics from swine wastewater in aerobic and anaerobic treatments followed the first order kinetic model. Under aerobic conditions, the biodegradation of antibiotics and hormones was correlated with nitrification rate, while in anaerobic conditions a relationship with methanogenic rate was found (Alvarino et al., 2014). Two mechanisms contribute to the biodegradation processes, i.e. metabolic and co-metabolic pathways by microorganisms. On one hand they can be used as a sole carbon and nitrogen source for the growth of microorganisms, while on the other hand they are degraded by enzymes secreted by microbial community. Their biodegradation depends on the presence of readily available organic matter, indicating the occurrence of cometabolism (Oliveira et al., 2016).

According to the review papers by Fischer and Majewsky (2014) and Quintana et al. (2005) co-metabolic biodegradation may play a major role in the removal of antibiotics and hormones during biological treatment processes since their concentrations could be too low to serve as a direct growth substrate. Although SMX was able utilized by activated sludge as carbon and/or nitrogen source, its biodegradation could be enhanced with the supply of readily degradable carbon source and deficiency of nitrogen conditions. As well, the author found two metabolic bacteria groups might be responsible for SMX biodegradation. They are heterotrophic bacteria assimilating SMX-C and/or SMX-N and autotrophic nitrifying bacteria oxidizing the functional amino group on the aromatic ring of SMX. 3-amino-5-methylisoxazole was the main stable metabolite when utilized SMX as a co-substrate, whereas, with SMX with the sole carbon and nitrogen source, hydroxyl-N-(5-methyl-1,2-oxazole-3yl)benzene-1-sulfonamide might be its metabolite (Müller et al., 2013). In addition, a bacterial strain named strain S-3, which was isolated from aerobic sludge and was identified as Achromobacter sp. has proven able to degrade $\mathrm{SMZ}$, and the maximum degradation rate 
attained $33.4 \%$ at $\mathrm{pH} 7.0$ and temperature of $30^{\circ} \mathrm{C}$ (Huang et al., 2012). In swine wastewater, microbial degradation is a major process resulting in the removal of TCs and could be enhanced by the addition of enzyme extract from spent mushroom compost of Pleurotus eryngii (Chang et al., 2014). However, the removal efficiencies of the three TCs (TC, OTC and CTC) were enhanced with the addition of extract-containing microcapsules rather than suspended enzyme extract in swine wastewater. The microorganism strains isolated from the wastewater samples, strain HL2 (identified as Xanthobacter flavus) indicated the best degrading ability of TCs (Chang et al., 2014).

Previous studies demonstrated that heterotrophic bacteria, ammonia oxidizing bacteria and nitrifying bacteria in biological processes were responsible for the degradation of estrogens (Amin et al., 2017; Pauwels et al., 2008; Shi et al., 2011). For example, the nutrient removal process revealed the removal of augmented hormones, in which these hormones were degraded through co-metabolism by the ammonium mono-oxygenase enzyme and heterotrophs cultures in the presence of other organic substances (Dytczak et al., 2008; Khunjar et al., 2011). In addition, Amin et al. (2017) reported that the removal rates of E2 were higher than E1 and EE2 in a moving bed bioreactor. Since E2 was converted to E1 at first stage of degradation, both E1 and E2 can be degraded in nitrifying and denitrifying conditions. However, the co-metabolism of EE2 was accomplished in enrich nitrifying cultures, which was consistent with the review report by Cajthaml et al. (2009). Specifically, according to the study of Pauwels et al. (2008), six bacterial strains belong to the $\alpha, \beta$ and $\gamma$ Proteobacteria Phylum were isolated from compost, which can grow on natural E1, E2 and E3 at low concentration $(\mu \mathrm{g} / \mathrm{l})$. Although the recalcitrant EE2 could not be metabolized by these bacteria, it was cometabolized in the presence of E1, E2 and E3._Estrogen-degrading bacteria were also isolated from an activated sludge bioreactor treating swine wastewater, which belongs to the genera of Methylobacterium, Ochrobactrum, Pseudomonas and 
Mycobacterium, respectively. Under the action of above estrogen-degrading bacteria, E1 and

338 E2 with a concentration of $1 \mathrm{mg} / \mathrm{L}$ could be removed $99 \pm 1 \%$ in $48 \mathrm{~h}$ (Isabelle et al., 2011).

339 The degradation of the parent hormone and its metabolites were successfully simulated by a

340 reversible first-order kinetic model under anaerobic conditions (Zheng et al., 2012).

341 For antibiotics and hormones in wastewater, their biodegradability is limited by their 342 bioavailability, since the first phase of the biodegradation process is taking them into the 343 internal cell, which leads to affinity of the compound with the bacterial enzymes (Luo et al., 344 2014). Thus, the solubility of antibiotics and hormones in aqueous medium can affect their 345 biological degradation potential (Cirja et al., 2008). The biodegradation starts when SMs 346 have fully established sorption equilibrium with the activated sludge, or the microorganisms 347 prefer to utilize readily biodegradable substrates before the antibiotics are degraded (Sahar et 348 al., 2011; Yang et al., 2012).

\section{Bioprocesses for removing antibiotics and hormones from swine wastewater}

\subsubsection{Activated sludge (AS) processes}

As the most common biological wastewater treatment process, activated sludge treatment can be used to treat sewage, industrial wastewater and agriculture wastewater (Suto et al., 2017; Suzuki et al., 2010). For swine wastewater, which contains high concentrations of organic matter, nutrients and suspended solids, it is hard for the effluent from conventional activated sludge treatment plants to meet the discharge standard (Joo et al., 2006; Sombatsompop et al., 2011). In recent years, because of the widespread use of activated sludge processes and large amounts of residual veterinary medicine in wastewater, a series of studies have started to focus on the fate and behavior of antibiotics and hormones in the activated sludge processes (Hamid \& Eskicioglu, 2012; Kim et al., 2013; Montes et al., 2015; 
361 Nguyen et al., 2013). Table 2 summarizes some studies examining the removal efficiency of 362 antibiotics and hormones in AS processes.

363 Generally, conventional activated sludge treatment involves two stages: primary 364 treatment (physicochemical) and secondary (biological) treatment; in some cases, tertiary 365 treatment is also included to improve effluent quality and achieve water reuse purpose. The 366 primary stage includes mechanical and flocculation-coagulation processes, and biosorption 367 was regarded as the main removal mechanism for antibiotics and hormones in this stage, 368 although some degradation could also occur. Thus, only those substances with higher 369 sorption properties are expected to be eliminated in the primary stage (Luo et al., 2014). For 370 example, Choi et al. (2008) have shown that coagulation could remove $43-94 \%$ TCs from 371 synthetic water. The study at two different full-scale swine manure-activated sludge treatment 372 plants also demonstrated the removals of OTC, CTC and DC (71\%-76\%, 75\%-80\% and 95\%) 373 did partly contribute to the flocculation-coagulation process (Montes et al., 2015). Regarding 374 hormones, although natural estragon E1 (7\%) and E2 (0\%) indicated little had been removed, 375 it has been reported that synthetic estragon (EE2) was removed in large amounts through the 376 primary process (Luo et al., 2014; Suárez et al., 2008). However, the removal efficiency of 377 antibiotics and hormones by such physicochemical methods has proved to be very limited 378 (less than 30\%) according to some research (Luo et al., 2014; Stackelberg et al., 2007; Vieno 379 et al., 2007). For the high water solubility compounds like SMX, the removal rate through the 380 primary treatment stage can be neglected. 
382 Removal of target antibiotics and hormones during AS processes

\begin{tabular}{|c|c|c|c|c|c|c|}
\hline Compounds & Wastewater source & $\begin{array}{l}\text { Initial concentrations } \\
(\mu \mathrm{g} / \mathrm{L})\end{array}$ & $\begin{array}{l}\text { Treatment } \\
\text { processes }\end{array}$ & Operation conditions & $\begin{array}{l}\text { Removal } \\
\text { efficiencies }\end{array}$ & References \\
\hline \multirow{3}{*}{ SMZ } & Swine wastewater & / & $\mathrm{A} / \mathrm{O}$ & $\mathrm{HRT}=72 \mathrm{~h}$ for each unit & $0 \%$ & $\begin{array}{l}\text { (Chen et al., } \\
\text { 2012b) }\end{array}$ \\
\hline & Synthetic wastewater & 5000 & SBR & $\begin{array}{l}\mathrm{SRT}=5 \text { and } 25 \mathrm{~d}, \mathrm{HRT}=3 \\
\mathrm{~h}, \mathrm{pH}=7.0 \mathrm{~T}=30^{\circ} \mathrm{C}\end{array}$ & $45 \%-80 \%$ & $\begin{array}{l}\text { (Huang et al., } \\
\text { 2012) }\end{array}$ \\
\hline & Swine wastewater & $100,500,3000$ & SBR & $\begin{array}{l}\mathrm{pH}=8.7 \pm 0.2, \mathrm{~T}= \\
20^{\circ} \mathrm{C}, \mathrm{MLSS} \approx 8000 \mathrm{mg} / \mathrm{L}\end{array}$ & $0 \%$ & (Ben et al., 2014) \\
\hline
\end{tabular}




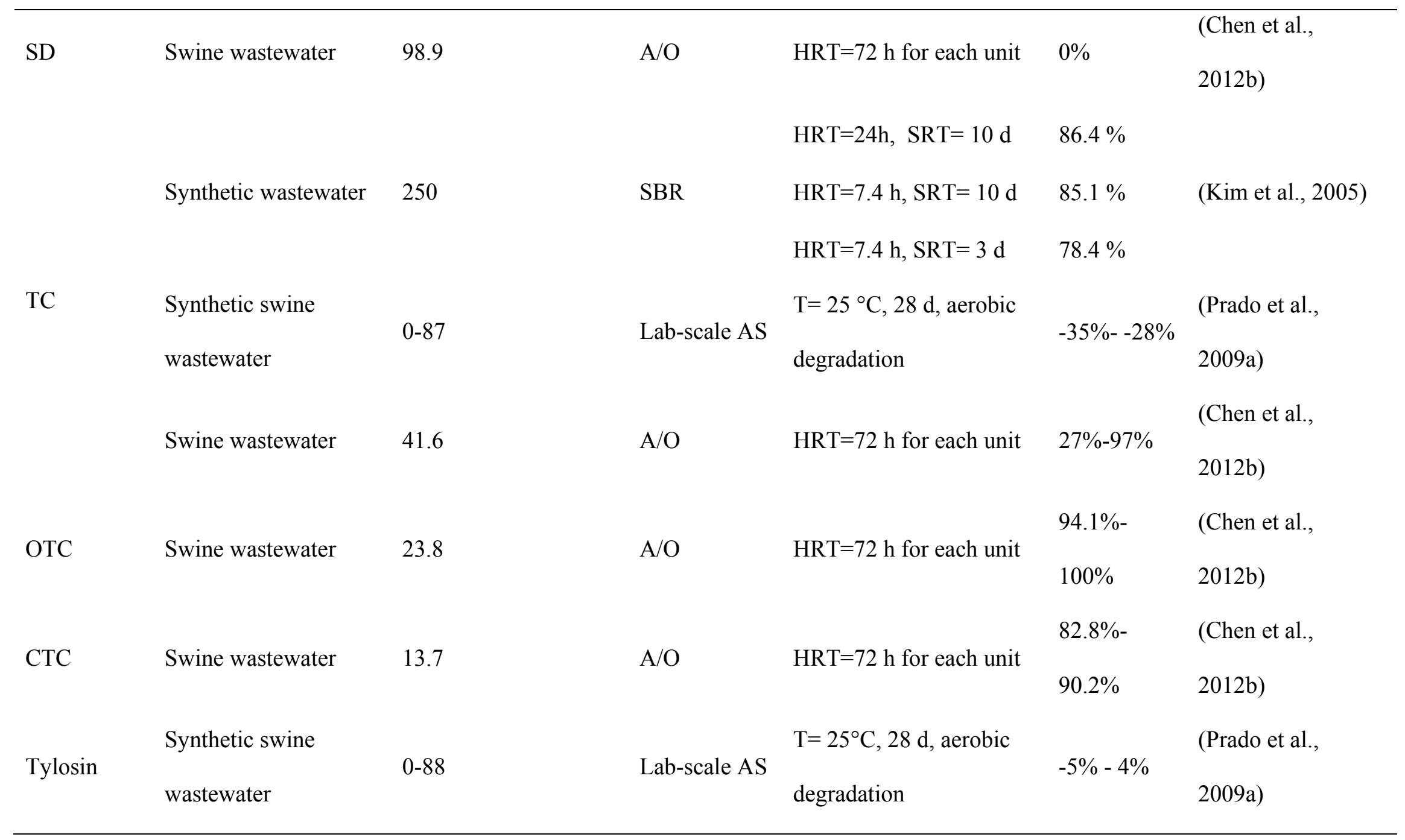




\begin{tabular}{|c|c|c|c|c|c|c|}
\hline E2 & Municipal wastewater & / & $\mathrm{A}^{2} \mathrm{O}$ & $\begin{array}{l}\mathrm{HRT}=8 \mathrm{~h}, \mathrm{SRT}=20 \mathrm{~d}, \\
\mathrm{~T}=20^{\circ} \mathrm{C}\end{array}$ & $99.99 \%$ & (Li et al., 2011) \\
\hline EE2 & Municipal wastewater & / & $\mathrm{A}^{2} \mathrm{O}$ & $\begin{array}{l}\mathrm{HRT}=8 \mathrm{~h}, \mathrm{SRT}=20 \mathrm{~d}, \\
\mathrm{~T}=20^{\circ} \mathrm{C}\end{array}$ & $80 \%$ & (Li et al., 2011) \\
\hline
\end{tabular}


By contrast, the secondary activated sludge process is the main stage for the elimination 384 of antibiotics and hormones by both biosorption and biodegradation (Li \& Zhang, 2010; 385 Yang et al., 2011; Zhou et al., 2013). Biosorption onto activated sludge is believed to be the 386 first and most rapid step and more important than the following biodegradation process (Ben 387 et al., 2014; Yang et al., 2012; Yang et al., 2011). For example, a research on the behavior of 388 sulfamethazine (SMZ) in an activated sludge process indicated a rapid and high adsorption (Ben et al., 2014). The high adsorption removal of SMZ in this study is mainly attributed to a large variety of organic materials and nutrients in swine wastewater, so that the acclimated activated sludge could have more carboxylic and phenolic moieties to form hydrogen bonds with the amine groups of SMZ, as well as the higher MLSS (8000 mg/L) and longer SRT (30 d). Thus, the biosorption process of antibiotics and hormones is influenced by MLSS and SRT of the wastewater. It was also reported no biodegradation was observed, and biosorption was found to be the principal removal mechanism of TC in AS processes (Batt, Kim \& Aga, 2007). Similarly, according to the research by Chen et al. (2012b), under long contact time of antibiotics with activated sludge, although tetracycline antibiotics TC, OTC, and CTC could be highly removed from swine wastewater by the $\mathrm{A} / \mathrm{O}$ process, no removal was observed for other antibiotics like SMX, SD, and SMZ. Thus, the author concluded that biosorption played the significant role for TCs removal in the activated sludge process, and the effluent water from this wastewater treatment system might pose risks to the aquatic environment in the vicinity of the swine farms. In addition, the conventional activated sludge process did not effectively contribute to the removal ARGs from wastewater, it has been reported as a hotspot for the release of ARGs into the environment (Hong et al., 2013; Rizzo et al., 2013). The proliferation of ARGs mainly occurs in activated sludge process, which potentially 
creates suitable conditions to microorganisms for selecting and spreading ARGs (Gao et al., 2015).

Referring to hormones, in the early 1990s the removal of hormones by the activated 410 sludge process was studied in Germany, Canada and Brazil, and the removal efficiency for 411 E2 and EE2 was $99.9 \%$ and $64 \%$, respectively, after the aerobic activated system (Ternes et 412 al., 1999). According to previous reports, both biosorption and biodegradation were 413 responsible for the removal of estrogenic hormones from wastewater in activated sludge 414 systems (Joss et al., 2004; Li et al., 2011). They were easily adsorbed onto the activated 415 sludge and further biodegraded. A laboratory-scale anaerobic-anoxic-oxic $\left(\mathrm{A}^{2} \mathrm{O}\right)$ activated 416 sludge system demonstrated that $99.99 \%$ of E2 was biodegraded and only $0.01 \%$ remained in 417 the waste sludge, and the anaerobic, anoxic and oxic reactors accounted for $71 \%, 7 \%$ and $22 \%$ 418 of the overall E2 removal, respectively. As for EE2, the removal efficiency was about $80 \%$, 419 and the anaerobic, anoxic and oxic reactors were responsible for $44 \%, 8 \%$ and $48 \%$ of the 420 overall EE2 removal, respectively. E2 was degraded in all three units of the $\mathrm{A}^{2} \mathrm{O}$ system, 421 while EE2 was only degraded in the anoxic and aerobic units ( $\mathrm{Li}$ et al., 2011). Thus, 422 biodegradation was more important for the removal of estrogens, especially the natural 423 estrogen, and aerobic conditions were the most favorable for their biodegradation (Hamid \& 424 Eskicioglu, 2012).

425 Prolonging SRT and HRT of AS processes can enhance the removal efficiency of antibiotics and hormones both through biosorption and biodegradation (Batt, Kim \& Aga, 427 2007; Kim et al., 2005). For example, Huang et al. (2012) reported that the increase of HRT 428 not only improved treatment performance of SMZ and COD but also provided a longer 429 period for microbes to acclimatize to SMZ, and the SMZ removal efficiency increased from $43045 \%$ to $80 \%$ as SRT was increased from 5 to 20 d. The optimal HRT and SRT for both 431 nutrient and SMZ removal were $3 \mathrm{~h}$ and $20 \mathrm{~d}$, respectively, mainly because longer HRT can 
432 offer more time for the biodegradation of pollutants. The increase of SRT could not only 433 influence the biota, through enriching the slow growing bacteria and providing a more 434 diverse bio-consortium, but also affect the physical nature of the floc particles, which have 435 exopolymer coatings comprised largely of polysaccharide and proteins. Obviously it would 436 have an important effect on their affinity as sorbents for the adsorbent compounds (Johnson, 437 Belfroid \& Di Corcia, 2000). Additionally, the removal efficiency of antibiotics was affected 438 by the changes in temperature. Relatively high temperatures like those in summer season $439\left(17^{\circ} \mathrm{C}-30^{\circ} \mathrm{C}\right)$ are favourable for removing antibiotics and hormones during conventional 440 activated sludge processes (Cirja et al., 2008). It is evident that temperature can influence not 441 only microbial activity, but also the adsorption equilibrium of pollutants in activated sludge. 442 Zhou et al. (2013) demonstrated that through the activated sludge treatment, removal 443 percentages of SMs ranged between 83.3-94.8\% in May of South China (warm climate), but 444 between $58.8-73.8 \%$ in November (cold climate) of that district.

445 Although the conventional activated sludge process is widely used for wastewater 446 treatment, and can achieve high organic removal efficiency, the treatment system is not 447 sufficient for removing persistent antibiotics and hormones. For example, the activated 448 sludge processes like sequencing batch reactors (SBRs) have been commonly applied in large 449 scale swine farms to treat swine wastewater primarily for reducing macropollutants, including 450 chemical oxygen demand (COD), total nitrogen (TN), and total phosphorus (TP) (Chen et al., 451 2012b; Zhang et al., 2006). However, antibiotics such as SMs, TCs, and macrolides, could 452 not be completely eliminated by these biological processes (Ben et al., 2011; Onesios et al., 453 2009). Nonetheless, micropollutants such as various antibiotics (SMs, TCs, and macrolides) 454 could not be completely eliminated by these biological processes (Ben et al., 2011; Onesios et 455 al., 2009). In order to remove these refractory micropollutants the optimum operating 456 conditions, like long HRT and SPT, must be maintained. Typically, the SRT in conventional 
activated sludge systems is $3-8 \mathrm{~d}$ but no longer than $15 \mathrm{~d}$. Yet the contact time required for the activated sludge to degrade antibiotics and hormones is longer than the HRT provided by conventional activated sludge processes. Therefore high concentrations of antibiotics and hormones can be detected in the effluent of conventional wastewater treatment plants and receiving water.

As well, under short time contact of such toxicants with activated sludge, the majority of antibiotics and hormones can be removed from wastewater by biosorption on activated sludge. In that case, the adsorbed antibiotics and hormones will be introduced into the environment if no further treatments are employed to remove them from the sludge.

\subsubsection{Anaerobic digestion (AD) processes}

From a sustainability perspective, the anaerobic digestion (AD) process is often considered as an alternative method for swine wastewater treatment, and has been widely applied in large-scale animal farms (Cheng \& Liu, 2002; Deng et al., 2006; Kim et al., 2012; Lo et al., 1994; Zhang et al., 2011b). The AD process has a number of advantages over the AS process for treating swine wastewater in that it needs no extra aeration equipment, less energy investment and generate fewer quantities of excess sludge. Moreover, the biogas generated during anaerobic digestion could serve as an attractive source of renewable energy to replace fossil fuel, while the digestate can serve as a fertilizer on farmland (Angelidaki et al., 2003; Barber \& Stuckey, 1999; Cheng \& Liu, 2002; Zhao et al., 2016).

According to the review paper by Sakar et al. (2009), anaerobic treatment processes like up-flow anaerobic sludge blanket (UASB), anaerobic sequencing batch reactor (ASBR), anaerobic baffled reactors, and continuously stirred tank reactor (CSTR) can be successfully utilized for swine waste treatment in both mesophilic and thermophilic conditions. However, high concentrations of suspended solids and ammonia nitrogen in swine wastewater affect the degradation efficiency of the anaerobic reactor, the treated water from anaerobic systems still 
contains high concentrations of ammonia nitrogen and COD, does not meet the discharge requirement. Thus, normally, post-treatment processes are needed for digested swine wastewater (Guo et al., 2013; Zhou et al., 2016). Furthermore, antibiotics and hormones residues in digestates show that the full removal capacity cannot be guaranteed through the $\mathrm{AD}$ process. It will in fact introduce a high risk to the environment after its land application (Widyasari Mehta et al., 2016a). In recent years, due to the high application of AD systems in livestock wastewater treatment, researchers began investigating the removal efficiency of antibiotics and hormones from wastewater using AD processes (Chen et al., 2012c; Furuichi et al., 2006; Stone et al., 2009; Suzuki et al., 2009; Widyasari Mehta et al., 2016b). The AD system can degrade antibiotics to various extents depending on the concentration and class of antibiotics, bioreactor types, operating conditions, etc.

As shown in Table 3, the efficiency in removing TCs and tylosin from wastewater using AD processes was better than that of SMs and estrogenic hormones. Chen et al. (2012b) investigated the occurrence and elimination of 14 selected antibiotics including TCs and SMs in two swine wastewater treatment systems (AD system and $\mathrm{A} / \mathrm{O}$ system) in east China. They found that the AD process can significantly degrade higher levels of TCs $(48.9 \%$ for TC and $96.7 \%$ for OTC), while the removal rate of SMs was much lower, only $8.3 \%$ and $31 \%$ for SD and SMX respectively. They concluded that the efficiency of removing antibiotics with AD technology was significantly poorer than that in anoxic and aerobic biological treatments. Although large amounts of TCs were removed from the water phase, effluent and sludge from such conventional wastewater treatment systems can still pose risks to the aquatic environment in the vicinity of swine farms because of high concentrations of antibiotics remaining in effluent water (Chen et al., 2012b).

The removal of TCs from liquid swine manure by the AD process also indicated high efficiency (Stone et al., 2009; Widyasari Mehta et al., 2016b). For example, when spiked 
507 OTC of $13.5,56.9$ and $95.0 \mathrm{mg} / \mathrm{L}$ appeared in swine manure, the removal rate employing the $508 \mathrm{AD}$ process was $57.8 \%, 53.3 \%$, and $67.7 \%$ respectively. CTC with initial concentrations of $5099.8,46.1$ and $74.0 \mathrm{mg} / \mathrm{L}$ could be removed, respectively $82.7 \%, 91.3 \%$ and $89.9 \%$ (Álvarez et 510 al., 2010). Tong et al. (2012) indicated the degradation rates of TC and CTC were $88.6 \%$ $51191.6 \%$ and 97.7\%-98.2\%, respectively, in $45 \mathrm{~d}$ anaerobic digestion. However, for removing $512 \mathrm{TC}(250 \mu \mathrm{g} / \mathrm{L})$ from synthetic wastewater by a lab-scale anaerobic baffled reactor (ABR), the 513 removal rates were not as high as that from swine wastewater or liquid swine manure, 514 ranging from $14.97 \%$ to $67.97 \%$ ( $\mathrm{Lu}$ et al., 2016). Therefore, the large suspended solids in 515 swine wastewater and slurry in liquid swine manure play a significant role in the adsorption 516 removal of TCs.

517 Table 3

518 Removal of target antibiotics and hormones during AD processes

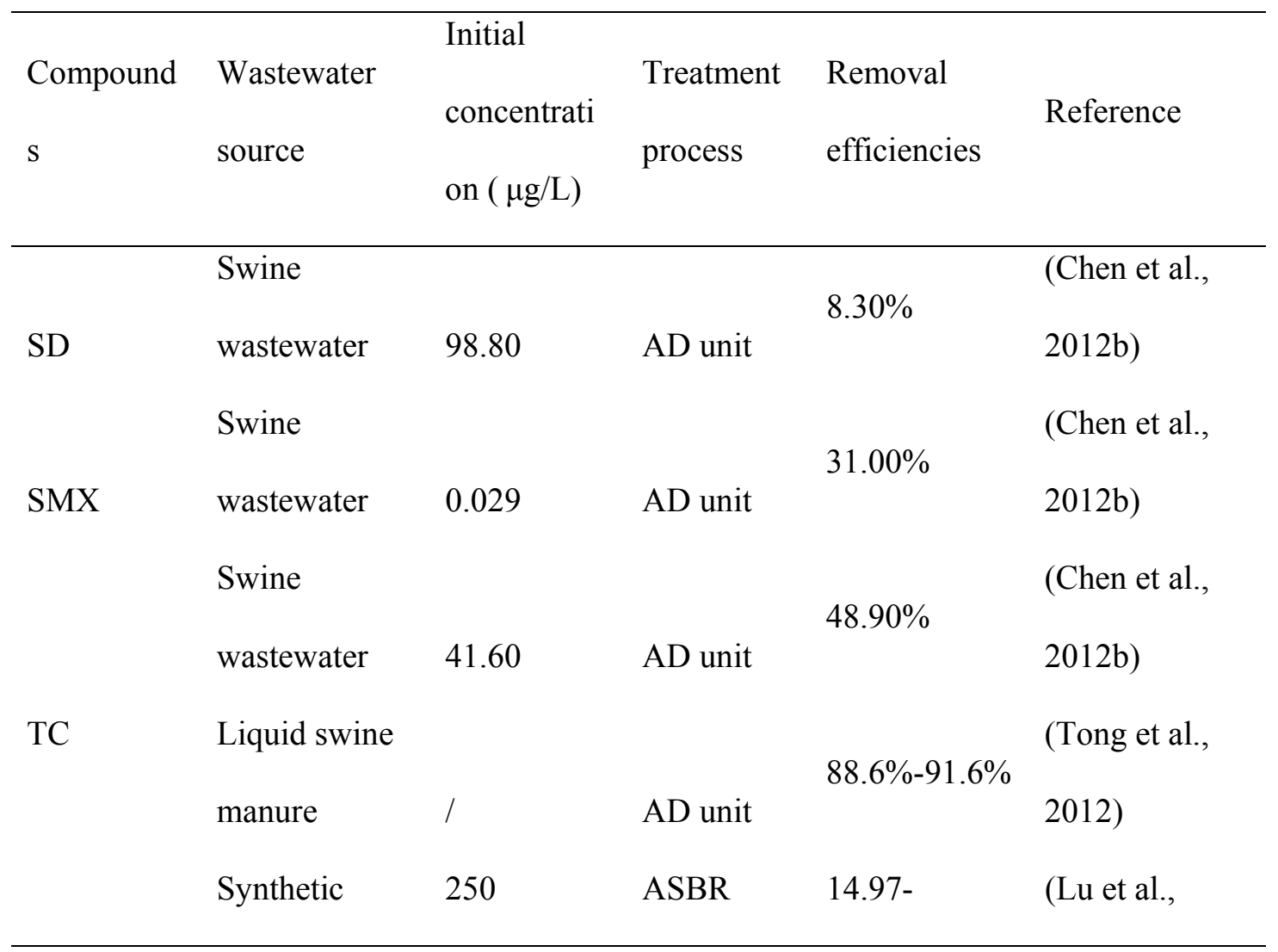




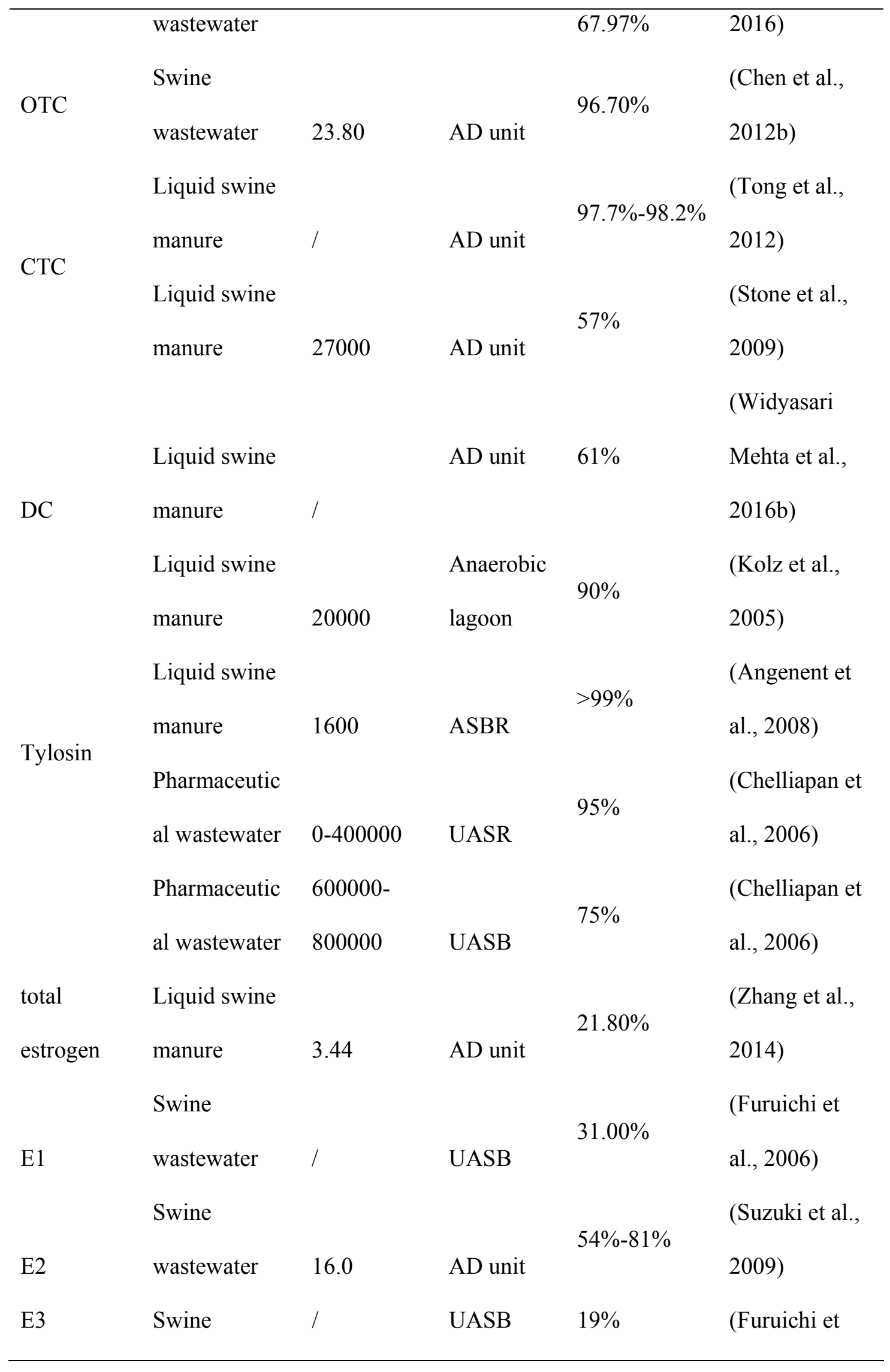




wastewater al., 2006)

However, the studies by Angenent et al. (2008) and Kolz et al. (2005) indicated that both biosorption and biodegradation were responsible for the removal of tylosin from liquid swine manure. For example, in an anaerobic sequencing batch reactor (ASBR), the removal rate of tylosin was more than $99 \%$ (from $1.6 \mathrm{mg} / \mathrm{L}$ to undetectable), and degradation was regarded as the main removal mechanism because the half-life of tylosin $(2.49 \mathrm{~h})$ in anaerobic treatment systems was shorter than the HRT (5-20 d) of the ASBR. The appearance of the metabolite (dehydroxy-tylonolide) of tylosin in the ASBR system also confirmed its degradation (Angenent et al., 2008). Conversely, Kolz et al. (2005) indicated large amounts of tylosin still remained in the slurry after eight months of anaerobic incubation, although its removal rate from swine slurries was up to $90 \%$ during 30 to $130 \mathrm{hrs}$ anaerobic incubation in anaerobic lagoon treatment. A high removal rate of tylosin (an average of 95\%) was also shown in an up-flow anaerobic stage reactor (UASR) treating pharmaceutical wastewater containing macrolide antibiotics (Chelliapan et al., 2006).

The reduction efficiency of ARGs in AD processes needs more attention because of the usual land application of AD products. The copy number of ARGs could be effectively reduced by AD processes (approximately 0.21-1.34 logs) (Sui et al., 2016; Wang et al., 2017). As reported, stable operational and longer SRT of AD could improve the removal of ARGs, as well, microbial community, environmental factors and nutrient level of tested samples played important roles in the abundance of ARGs along the swine waste treatment (Song et al., 2017a; Wang et al., 2016).

The presence of antibiotics in $\mathrm{AD}$ processes has the potential to compromise the system's performance. Different classes, concentrations and addition methods of antibiotics show various levels of inhibition (Álvarez et al., 2010; Chen et al., 2017b; Lu et al., 2016; Stone et al., 2009). For example, Álvarez et al. (2010) reported $\mathrm{CH}_{4}$ productions were 
543 reduced by $56 \%, 60 \%$ and $62 \%$ in digesters as TCs were added at concentrations of $10 \mathrm{mg} / \mathrm{L}$, $54450 \mathrm{mg} / \mathrm{L}$ and $100 \mathrm{mg} / \mathrm{L}$, respectively. About $27.8 \%$ and $28.4 \%$ of $\mathrm{CH}_{4}$ and $\mathrm{CO}_{2}$ productions 545 were inhibited due to the presence of CTC in ASBRs (Stone et al., 2009). For the treatment of 546 synthetic wastewater containing TC $(250 \mu \mathrm{g} / \mathrm{L})$ in a lab-scale Anaerobic Baffled Reactor 547 (ABR), the inhibition of biogas production was also observed, while $\mathrm{H}_{2}$ production and VFAs 548 accumulation were not affected. Thus, Lu et al. (2016) indicated that the presence of TC 549 exerted less influence on the degradation of organic matter, but had a strong influence on 550 biogas generation. However, Dreher et al. (2012) noted that $28 \mathrm{mg} / \mathrm{L} \mathrm{CTC}$ did not inhibit 551 biogas production. SMs also revealed no observed effect on biogas production in the AD 552 process when their concentration in wastewater was less than $280 \mathrm{mg} / \mathrm{L}$ (Mitchell et al., 553 2013). Chen et al. (2017b) pointed out the inhibitory effects of SMX on the performance of 554 the UASB system depend on the SMX concentration, pre-exposure time in the experiment 555 and operation conditions. Some researchers discovered that SMX with a concentration of 6$556100 \mathrm{mg} / \mathrm{L}$ and $\mathrm{SMs}$ with a total concentration of $28 \mathrm{mg} / \mathrm{L}$ did not inhibit the production of 557 biogas (Chen et al., 2017b; Gartiser et al., 2007; Mohring et al., 2009).

558 As mentioned above, during the ASBR process the average concentration of tylosin at $5591.6 \mathrm{mg} / \mathrm{L}$ did not impact on the performance of swine waste digestion, since total methane 560 production, VS removal, and effluent chemical oxygen demand did not change significantly. 561 However, after the addition of $167 \mathrm{mg} / \mathrm{L}$ of tylosin to the reactor, a gradual decrease in $\mathrm{CH}_{4}$ 562 production and the accumulation of propionate and acetate were seen (Angenent et al., 2008). 563 The UASB system's performance was also influenced by the concentration of tylosin in 564 the influent. Chelliapan et al. (2006) concluded that concentrations of tylosin $\leq 400 \mathrm{mg} / \mathrm{L} \mathrm{had}$ 565 a negligible effect on reactor performance, while at concentrations of 600 and $800 \mathrm{mg} / \mathrm{L}$, the 566 COD reduction fell from $95 \%$ to $85 \%$ while the removal of tylosin declined from $95 \%$ to $56775 \%$. 
Biogas production could also be inhibited in $\mathrm{AD}$ processes by the presence of tylosin in wastewater, because tylosin inhibited propionate- and butyrate-oxidizing syntrophic bacteria and fermenting bacteria, which resulted in unfavorable effects on methanogenesis (Angenent

572 by $10 \%-20 \%$ at 130 and $260 \mathrm{mg} / \mathrm{L}$ of tylosin, and $30-38 \%$ at 520 and $913 \mathrm{mg} / \mathrm{L}$ of tylosin.

573 García-Sánchez et al. (2016) investigated the effect of various concentrations and addition 574 methods of tylosin on methanogenesis in an anaerobic treatment for swine wastewater. Their 575 results indicated that the presence of tylosin could inhibit the generation of $\mathrm{CH}_{4}$ even at 576 concentrations as low as $0.01 \mathrm{mg} / \mathrm{L}$, if biomass had no contact with the antibiotic in advance.

577 In contrast, if the biomass acclimated in the presence of tylosin at a concentration of 0.01 to $5780.065 \mathrm{mg} / \mathrm{L}$ at the beginning, methanogenesis was not inhibited in the presence of antibiotics. 579 The microorganisms had not only developed resistance to the antibiotics, but also the ability 580 to metabolize them (García-Sánchez et al., 2016). Huang et al. (2014a) and Huang et al. 581 (2014b) investigated the effects of different antibiotic addition methods (added antibiotics to reactor directly/ added the polluted pig manure to reactor) on methane production from the anaerobic digestion of swine wastes. They concluded that methane production was inhibited them, the degradation rate of antibiotics was improved.

The study on the effects of different antibiotics on the psychrophilic anaerobic digestion of swine manure slurry in ASBRs indicated that only penicillin and tetracycline had an inhibitory effect on $\mathrm{CH}_{4}$ production, when antibiotics (including tylosin, TC, SMZ, and penicillin) were individually added to the pig diet at their maximum prescribed level (Massé 
et al., 2000; Wu et al., 2011). Considering the average concentrations of antibiotics in swine

594

595

596

wastewaters and the accommodation of biomass, their inhibition seems negligible for the application of the AD process.

Normally, a warm temperature is required for methane-forming bacteria converting VFA to biogas. As reported elsewhere, mesophilic and thermophilic conditions are preferable for the removal of antibiotics (Carballa et al., 2007). Varel et al. (2012) indicated that CTC in swine manure can be reduced by $80 \%$ and $98 \%$ in anaerobic digesters at $38^{\circ} \mathrm{C}$ and $55^{\circ} \mathrm{C}$, but at $22^{\circ} \mathrm{C}$ it could only remove $7 \%$.

During $\mathrm{AD}$ processes, estrogenic hormones were less degradable than those in aerobic conditions (Combalbert \& Hernandez-Raquet, 2010; De Mes et al., 2008). De Mes et al. (2008) studied the fate of E1, E2 and EE2 in an UASB reactor treating concentrated black water. They indicated no significant removal of E1, E2 and EE2 was observed, and although adsorption was responsible for $32-35 \%$ removal of E1 and E2 from the liquid phase, the effluent still contained considerable concentrations of E1 $(4.02 \mu \mathrm{g} / \mathrm{L})$ and E2 $(18.79 \mu \mathrm{g} / \mathrm{L})$, with a large fraction existing in conjugated form. Similar results were concluded on the removal of estrogenic compounds in swine wastewater through a series of UASB and a trickling filter system in a swine farm waste treatment plant (Furuichi et al., 2006). The hybrid system proved to be efficient in removing estrogen and estrogenic activity (E1 and E2 respond for most of the estrogenic activity), with the removal rates for estrogen and estrogenic activity being 78\% and 97\%, respectively. However, Furuichi et al. (2006) demonstrated that the trickling filter reduced most of the estrogenic activity, while only about $23.2 \%$ of the estrogenic compounds were removed through the UASB process. Some researchers have shown that the degradation of estrogens was limited under anaerobic conditions, the removal efficiency was only $21.8 \%$, and the degradation of EE2 is undetectable (Czajka \& Londry, 2006; Zhang et al., 2014; Zheng et al., 2012). According to 
the report about anaerobic biotransformation of estrogens in the UASB reactor, E2 was the easiest degradable estrogen, while for E1, lower values were obtained $(<30 \%)$ as a result of the balance between E1 formation, metabolite of E2 and its own biodegradation.

However, an esoteric impediment in EE2 does not allow the formation of a ketone (as observed for E2) due to the presence of the group ethinyl in the position 17, so its removal efficiency is lower than E2 (Czajka \& Londry, 2006). Suzuki et al. (2009) indicated that the removal efficiencies of E2 were $54 \%-81 \%$ in an anaerobic plant treating swine wastewater, but the final effluent still contained $2 \mu \mathrm{g} / \mathrm{L}$ of E2 after treatment. The methane fermentation process was important not only for the generation of methane, but also for the removal of E2.

In contrast, the removal rates for E1 and E3 were only $31 \%$ and $19 \%$ respectively in an UASB system treating animal wastes (Combalbert \& Hernandez-Raquet, 2010). Similarly, although biogas digester and lagoon treatment systems can remove large quantities of progestogens in swine wastewater, the residual progestogens $(29.7 \mathrm{ng} / \mathrm{L}, 8.57 \mathrm{ng} / \mathrm{L}$, and 14.2 $\mathrm{ng} / \mathrm{L}$ in the nearby field ditches, wells, and receiving streams, respectively) will still pose potential risks to aquatic organisms. These include, for example fish in the receiving aquatic environments (Liu et al., 2015a).

In summary, although anaerobic digestion processes are energy-efficient and environmentally friendly processes compared to conventional activated sludge processes, their treatment efficiency for high-strength and toxicant swine wastewater is limited. Like conventional activated sludge processes, the effluent from such $\mathrm{AD}$ treatment plants is difficult to meet the discharge standard, not only for the traditional contaminants, but also for antibiotic and hormones. Consequently, more efficient and advanced processes are needed for the removal of antibiotics and hormones from swine wastewater. 


\subsection{Advanced treatment processes}

\subsubsection{Membrane bioreactor processes (MBRs)}

Considering the presence of high fractions of refractory organic matter in swine wastewater, membrane bioreactor processes are more efficient for their treatment compared with conventional treatment processes. Membrane bioreactors (MBRs) are a combination of adsorption, biodegradation and membrane separation processes that enable a high quality of effluent with very low amounts of total suspended solids (TSS), turbidity, biological oxygen demand (BOD), pathogens, etc.(Kim et al., 2008; Kornboonraksa et al., 2009; Zhou et al., 2016).

In MBRs, a high SRT within compact reactor volumes is achieved because it is possible to uncouple the HRT and SRT in tangential filtration, other than the traditional gravity settling in AS systems (de Cazes et al., 2014a). Compared with conventional processes, MBRs have a number of advantages, such as long SRT, flexibility in operation, compact plant structure, minimal sludge production, high nitrification performance, high biomass diversity, stable and excellent effluent quality suitable for reuse (Yang \& Cicek, 2008). Thus, MBRs are considered to be a promising alternative technology for treating highly contaminated swine wastewater. The average removal efficiencies of BOD, $\mathrm{COD}, \mathrm{NH}_{3}-\mathrm{N}$ and turbidity in MBR were more than 90\% (Kornboonraksa et al., 2009; Sui et al., 2014).

Considering these advantages of MBR systems, researchers have begun to study the performance of MBR systems for treating wastewater polluted by antibiotics and hormones (see Table 4). It emerged that the MBR systems functioned well for treating swine wastewater filled with much pollution containing antibiotics and hormones. Not only was the performance of MBR not significantly disturbed by the existence of antibiotics and hormones, but also such toxicants can be removed effectively in MBRs (Galán et al., 2012; Liu et al., 2016; Prado et al., 2009b; Song et al., 2017c). For example, Song et al. (2017c) indicated 
$66683.8 \%$ of 11 typical veterinary antibiotics could be removed from digested swine wastewater 667 in the MBR at the HRT of 5-4 d, although the removal rare decreased to $57.0 \%$ and $25.5 \%$ 668 when HRT was shortened to $3-2 \mathrm{~d}$ and $1 \mathrm{~d}$, and more than $90 \%$ of COD and $\mathrm{NH}_{3}-\mathrm{N}$ were 669 removed.

670 On this theme, Prado et al. (2009b) and Zhu et al. (2017) indicated that the impact of 671 antibiotics under a certain concentration in wastewater on the performance of the MBR 672 system was weak. Prado et al. (2009b) showed before and after TC injection the average 673 removal rates of COD were $92 \%$ and $88 \%$, respectively, and the ammonium removal 674 efficiency stayed at $99 \%$. As well, the removal rate of TC in this pilot scale MBR system was $67589 \%$ as the initial concentration of $2.5 \mathrm{mg} / \mathrm{L}$. Zhu et al. (2017) also stated that $100 \mu \mathrm{g} / \mathrm{L}$ of 676 SMX and TC had no effect on the removal of pollutants in an anoxic/aerobic MBR system, 677 may because microbial communities maintain system stability through gradual acclimation of 678 functional bacteria and development of potential antibiotic resistance species. Such results confirmed the ruggedness and superiority of MBR over conventional bioprocesses.

680 Similarly, an analysis on the removal of estrogenic activity (EA) from swine wastewater 681 by submerged MBRs demonstrated that the average removal rate of EA was $93.5 \%$ in the 682 soluble phase of swine wastewater, and $94.5 \%$ in total. During the steady-state operation 683 period total COD removal efficiencies ranged from $68.5 \%$ to $82.7 \%$, and the removal of $\mathrm{NH}_{3}-$ $684 \mathrm{~N}$ could be up to $99.9 \%$ with proper $\mathrm{pH}$ control. The author also indicated that although both 685 adsorption and biodegradation contributed to the removal of EA, biodegradation played a 686 more important role. This is because only a small fraction of EA remained $(9.4 \%$ in the 687 wasted sludge and 5.4\% in the accumulated bio-cake) (Yang \& Cicek, 2008).

688 High removal efficiency in MBRs is attributed to stable biomass concentration and 689 retention of particulate matter. These provide a stable scenario for the growth of a specialized 690 microbial community efficient in the biodegradation of toxicants. As well as better removal 
691 performance, the MBRs exhibited more stable functioning than the conventional treatment

692 system due to faster response to variable influent concentrations and operational perturbation

693 (De Wever et al., 2007). As well, the removal of ARGs in the MBR process was reported

694 significantly higher than that in conventional treatment systems. Compared with the 695 conventional activated sludge treatment process, concentrations of ARGs (tetW and tetO) and

696 16s rRNA gene in the MBR effluent were observed to be 1-3 log less (Munir et al., 2011).

697 Table 4

698 Removal of target antibiotics and hormones during MBRs processes

\begin{tabular}{|c|c|c|c|c|c|}
\hline Compounds & $\begin{array}{l}\text { Wastewater } \\
\text { source }\end{array}$ & $\begin{array}{l}\text { Initial } \\
\text { concentrations } \\
(\mu \mathrm{g} / \mathrm{L})\end{array}$ & $\begin{array}{l}\text { Treatment } \\
\text { process }\end{array}$ & $\begin{array}{l}\text { Removal } \\
\text { Efficiencies }\end{array}$ & Reference \\
\hline SMs & $\begin{array}{l}\text { Digested } \\
\text { swine } \\
\text { wastewater }\end{array}$ & 6.27 & $\begin{array}{l}\text { Lab-scale } \\
\text { MBR }\end{array}$ & $87.4 \%$ & $\begin{array}{l}\text { (Song et al., } \\
\text { 2017c) }\end{array}$ \\
\hline SMX & $\begin{array}{l}\text { Municipal } \\
\text { wastewater }\end{array}$ & l & $\begin{array}{l}\text { Pilot-scale } \\
\text { MBR }\end{array}$ & $80 \%$ & $\begin{array}{l}\text { (Göbel et al., } \\
\text { 2007) }\end{array}$ \\
\hline TCs & $\begin{array}{l}\text { Digested } \\
\text { swine } \\
\text { wastewater }\end{array}$ & 16.21 & $\begin{array}{l}\text { Lab-scale } \\
\text { MBR }\end{array}$ & $86.8 \%$ & $\begin{array}{l}\text { (Song et al., } \\
2017 \mathrm{c} \text { ) }\end{array}$ \\
\hline $\mathrm{TC}$ & $\begin{array}{l}\text { Digested } \\
\text { swine } \\
\text { wastewater }\end{array}$ & / & $\begin{array}{l}\text { Submerge } \\
\text { d MBR }\end{array}$ & $94 \%$ & $\begin{array}{l}\text { (Liu et al., } \\
\text { 2016) }\end{array}$ \\
\hline & $\begin{array}{l}\text { Digested } \\
\text { swine }\end{array}$ & 3.83 & $\begin{array}{l}\text { Lab-scale } \\
\text { MBR }\end{array}$ & $80.2 \%$ & $\begin{array}{l}\text { (Song et al., } \\
2017 \mathrm{c} \text { ) }\end{array}$ \\
\hline
\end{tabular}




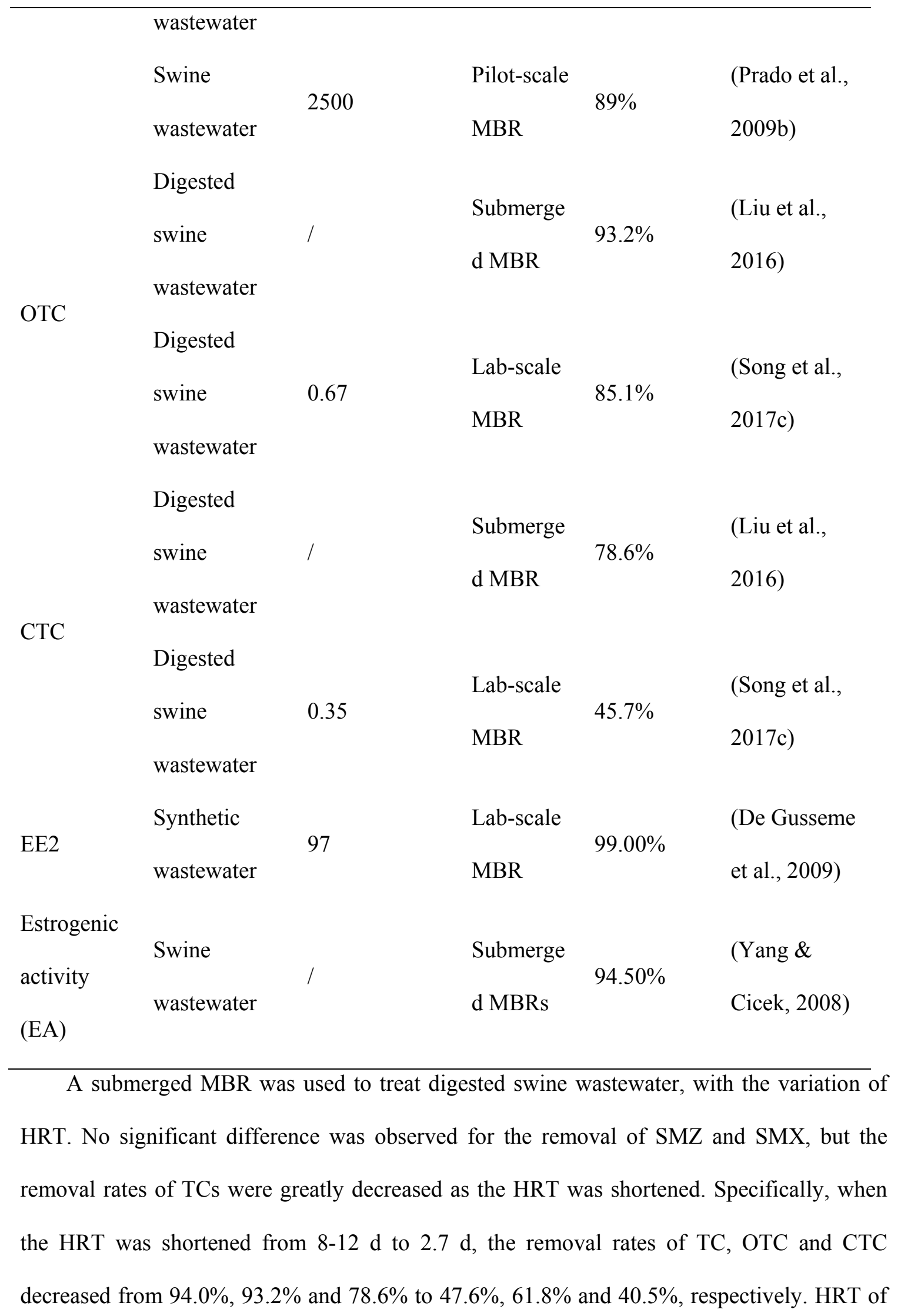


704 3-4 d was reported to be enough for the efficient removal of COD and ammonium from 705 digested swine wastewater, but insufficient for effectively removing antibiotics (Liu et al., 706 2016).

707 Similar to conventional technologies, the treatment of swine wastewater in a semi708 industrial MBR also indicated that longer SRT was beneficial for the removal of antibiotics. 709 The removal of TC was $89 \%$ at long SRT (10 d), while it decreased to $78 \%$ at a shorter SRT 710 (3 d). Thus, long SRT of the MBR (30 d) did enhance the adsorption of TC on the sludge surface and reduced its toxic impact (Prado et al., 2009b). Long SRT increased the growth of nitrifying bacteria, which led to large amounts of biodegradable micro-pollutants being removed. As reported by De Gusseme et al. (2009), 99\% of EE2 was removed in the nitrifier714 enriched biomass of MBR.

715 Compared with conventional treatment processes, the removal efficiency of MBR 716 systems is mainly influenced by the biological process and the membrane in MBR. 717 According to Ganiyu et al. (2015), the rejection of toxicants by membranes occurs mainly 718 through three mechanisms: size exclusion, hydrophobic interaction and electrostatic 719 interaction. Although the micro-filtration (MF) and ultra-filtration (UF) membranes could not 720 directly retain the small molecules like antibiotics and hormones, they could effectively retain 721 high concentrations of activated sludge with enriched microbial biodiversity, which 722 potentially contributed to the elimination of micro-organic pollutants (Xue et al., 2010). It is 723 reported that TCs had a high sorptive affinity on the membrane, and approximately $80 \%$ of 724 CTC and $50 \%$ of DC were adsorbed on the membrane surface.

725 However, the adsorption rates of hormones and SMs were lower than TCs, and the 726 rejection of SMs was the lowest among them. Koyuncu et al. (2008) found that adding 727 antibiotics to hormone solution increased the rate of hormone rejection. Among the widely 728 used membrane types, reverse osmosis (RO) membrane reported the highest rejection rate to 
most antibiotics and hormones, followed by nanofiltration (NF) membrane and ultrafiltration (UF) membrane, while the rejection of microfiltration (MF) membrane was the lowest (Luo et al., 2014). Sahar et al. (2011b) compared the removal efficiency of several macrolide and sulfonamide antibiotics from sewage by CAS coupled with UF and by a pilot MBR system. Their results showed that removing antibiotics via the MBR system was $15-42 \%$ higher than that of the CAS system, but this advantage was reduced to a maximum of $20 \%$ when the UF was added to the CAS. Based on the above results, the author hypothesized that the membrane in both systems only contributed to biosorption removal of antibiotics rather than improvement in biodegradation (Sahar et al., 2011b).

However, some researchers demonstrated that the membrane in MBRs systems could not only enhance the adsorption of toxicants onto suspended sludge, but also increase its biodegradation ability. This is because the longer SRT and the sludge with higher concentrations of biomass and more effective surface in MBRs permitted sufficient adaption for heterotrophs to degrade persistent pollutants and growth of slow growers such as nitrifiers (Galán et al., 2012; Sahar et al., 2011a). For example, the stubborn TCs in swine wastewater showed an absence of biodegradability since the biodegradation rates were $-28 \%$ and $-35 \%$ in activated sludge systems (Prado et al., 2009a). Similarly, Göbel et al. (2007) demonstrated that the removal of SMX in MBR was significantly better than in conventional AS processes ( $80 \%$ and $60 \%$, respectively), and biodegradation played a major role in the removal of SMX, while only a small portion of the removal was caused by biosorption $(5-10 \%)$.

The biodegradation removal of EE2, as mentioned above, is attributed to nitrifying microorganisms through a co-metabolism performed by the enzyme ammonium monooxygenase (Shi et al., 2004; Yi \& Harper, 2007). The growth of the autotrophic microorganisms in conventional AS processes was much slower than that in MBR due to shorter SRT, which limited the biodegradation of EE2 in conventional AS processes. EE2 with lower 
biodegradability and higher hydrophobicity was primarily removed by biosorption in AS systems, but can be biodegraded in MBR (Clouzot et al., 2010).

However, high energy consumption and operating costs relating to membrane fouling are the most serious drawbacks of MBRs systems. This is because in order to decrease the membranes' fouling and clogging, continuous aeration in the lower part of the membrane bundle is generally necessary (de Cazes et al., 2014a).

\subsubsection{Constructed wetlands (CWs)}

Constructed wetlands are implemented widely in rural areas to treat swine wastewaters because of they are inexpensive and simple to operate compared to other market wastewater treatment technologies (Garcia-Rodríguez et al., 2014). Wastewater treatment is achieved through an integrated combination of physical, chemical, and biological interactions among vegetation, substrates, soils, microorganisms and water to remove various contaminants and improve the water quality (Wu et al., 2015).

According to the wetland hydrology (free water surface and subsurface systems) and water flow direction, CWs could be classified as: firstly, free water surface constructed wetlands (SF-CWs); secondly, horizontal subsurface flow constructed wetlands (HSSF-CWs); and thirdly, vertical subsurface flow constructed wetlands (VSSF-CWs) (Töre et al., 2012). In these CWs systems, various removal processes can take place: adsorption on the substrates, plant uptake, phytovolatilization, release of exudates, oxygen pumping into the rhizosphere, and microbial degradation (Carvalho et al., 2013). Since the first experiments using constructed wetland for wastewater treatment were carried out by Käthe Seidel in Germany in the early 1950s, many studies since then have demonstrated that constructed wetlands (CWs) can efficiently remove organics, nutrients, heavy metals, and other components from wastewater (Wu et al., 2015). 
In recent years, several studies have attempted to remove antibiotics and hormones from swine wastewater by $\mathrm{CWs}$, and their treatment efficiencies differed depending on various configurations and compounds (Hsieh et al., 2015; Huang et al., 2017; Klomjek, 2016; Liu et al., 2013; Papaevangelou et al., 2016; Shappell et al., 2007), as shown in Table 5. Carvalho et al. (2013) reported that removal rates of TC and enrofloxacin (ENR) were at least $94 \%$ and $98 \%$, respectively, using microcosm VSSF-CWs to treat swine wastewater containing 100 $\mu \mathrm{g} / \mathrm{L}$ of such antibiotics. For the synthetic swine wastewater containing $40 \mu \mathrm{g} / \mathrm{L}$ of CTC, OTC and SMZ, the removal efficiencies when utilizing CWs were 78\%-85\%, 91\%-95\%, and 68\%-73\%, respectively (Liu et al., 2013). Huang et al. (2017) constructed mesocosm VSSFCWs to treat swine wastewater with $250 \mu \mathrm{g} / \mathrm{L}$ OTC and difloxacin (DIF). The results revealed that the average mass removal efficiencies of OTC and DIF were higher than $90 \%$. For the removal of ARGs, the absolute abundances of sulfonamide resistance genes (sulI, sulII, sulIII) and tetracycline resistance genes (tetO, tetM, tetW, tet $\mathrm{A}$, tetX) were reduced from swine wastewater without significant difference among different types of CWs. Whereas, the relative abundances of most target genes in the CWs showed obvious increases over the treatment period (Huang et al., 2015; Liu et al., 2013a; Liu et al., 2014; Zhang et al., 2017). The abundance of ARGs in CWs may be affected by the characteristic of wastewater, operating conditions and configuration of CWs (Huang et al., 2017; Sharma et al., 2016).

Estrogenic hormones also can be removed effectively from swine wastewater by CWs processes (Shappell et al., 2007; Song et al., 2009). Shappell et al. (2007) operated a lagoonconstructed wetland system to treat the hormonal activity in swine wastewater, and demonstrated that wetlands reduced estrogenic activity by $83-93 \%$ at variational HRT ranging from 22 to $50 \mathrm{~d}$. 
804

805

Table 5

806 Removal of target antibiotics and hormones during CWs processes

\begin{tabular}{|c|c|c|c|c|c|}
\hline Compounds & $\begin{array}{l}\text { Wastewater } \\
\text { source }\end{array}$ & $\begin{array}{l}\text { Initial } \\
\text { concentrations } \\
(\mu \mathrm{g} / \mathrm{L})\end{array}$ & Treatment process & $\begin{array}{l}\text { Removal } \\
\text { efficiencies }\end{array}$ & Reference \\
\hline \multirow{2}{*}{ SMZ } & $\begin{array}{l}\text { Swine } \\
\text { wastewater }\end{array}$ & 40 & $\begin{array}{l}\text { Lab-scale VFCW } \\
\text { (zeolite/ volcanic } \\
\text { rock-medium) }\end{array}$ & $68 \%-73 \%$ & $\begin{array}{l}\text { (Liu et al., } \\
\text { 2013) }\end{array}$ \\
\hline & $\begin{array}{l}\text { Synthetic } \\
\text { swine } \\
\text { wastewater }\end{array}$ & 30 & $\begin{array}{l}\text { Pilot-scale } \\
\text { SFCW/HSFCW/ } \\
\text { VSF-LCW/ VSF- } \\
\text { HCW }\end{array}$ & $40 \%-87 \%$ & $\begin{array}{l}\text { (Liu et al., } \\
\text { 2014) }\end{array}$ \\
\hline \multirow{2}{*}{ TC } & $\begin{array}{l}\text { Swine } \\
\text { wastewater }\end{array}$ & 100 & $\begin{array}{l}\text { Microcosm VSSF- } \\
\text { CWs }\end{array}$ & $94 \%$ & $\begin{array}{l}\text { (Carvalho } \\
\text { et al., } \\
\text { 2013) }\end{array}$ \\
\hline & $\begin{array}{l}\text { Synthetic } \\
\text { swine } \\
\text { wastewater }\end{array}$ & 30 & $\begin{array}{l}\text { Pilot-scale } \\
\text { SFCW/HSFCW/ } \\
\text { VSF-LCW/ VSF- } \\
\text { HCW }\end{array}$ & $92 \%-99 \%$ & $\begin{array}{l}\text { (Liu et al., } \\
\text { 2014) }\end{array}$ \\
\hline OTC & $\begin{array}{l}\text { Swine } \\
\text { wastewater }\end{array}$ & 40 & $\begin{array}{l}\text { Lab-scale VFCW } \\
\text { (zeolite/ volcanic }\end{array}$ & $91 \%-95 \%$ & $\begin{array}{l}\text { (Liu et al., } \\
\text { 2013) }\end{array}$ \\
\hline
\end{tabular}


rock medium)

\begin{tabular}{|c|c|c|c|c|c|}
\hline & & & rock medium) & & \\
\hline & $\begin{array}{l}\text { Swine } \\
\text { wastewater }\end{array}$ & 250 & $\begin{array}{l}\text { Mesocosm VSSF- } \\
\text { CWs }\end{array}$ & $>90 \%$ & $\begin{array}{l}\text { (Huang et } \\
\text { al., 2017) }\end{array}$ \\
\hline & $\begin{array}{l}\text { Livestock } \\
\text { wastewater }\end{array}$ & $0.22 \pm 0.17$ & Full-scale SFCW & $97 \%$ & $\begin{array}{l}\text { (Hsieh et } \\
\text { al., 2015) }\end{array}$ \\
\hline E2 & $\begin{array}{l}\text { Livestock } \\
\text { wastewater }\end{array}$ & $0.19 \pm 0.27$ & Full-scale SFCW & $95.20 \%$ & $\begin{array}{l}\text { (Hsieh et } \\
\text { al., 2015) }\end{array}$ \\
\hline E3 & $\begin{array}{l}\text { Livestock } \\
\text { wastewater }\end{array}$ & $0.16 \pm 0.14$ & Full-scale SFCW & $76.60 \%$ & $\begin{array}{l}\text { (Hsieh et } \\
\text { al., 2015) }\end{array}$ \\
\hline EE2 & $\begin{array}{l}\text { Livestock } \\
\text { wastewater }\end{array}$ & $0.025 .8 \pm 0.039$ & Full-scale SFCW & $31.80 \%$ & $\begin{array}{l}\text { (Hsieh et } \\
\text { al., 2015) }\end{array}$ \\
\hline EA & $\begin{array}{l}\text { Swine } \\
\text { wastewater }\end{array}$ & / & $\begin{array}{l}\text { Lagoon- } \\
\text { constructed } \\
\text { wetland system }\end{array}$ & $83-93 \%$ & $\begin{array}{l}\text { (Shappell } \\
\text { et al., } \\
\text { 2007) }\end{array}$ \\
\hline
\end{tabular}

807

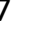

808

Among the above mentioned three types of CWs, VSSF-CWs was the most efficient in removing antibiotics and hormones (Huang et al., 2017; Liu et al., 2014). Liu et al. (2014) operated four pilot-scale constructed wetlands (free water surface (SF), horizontal subsurface flow (HSF), vertical subsurface flows with different water level (VSF-L) and $(\mathrm{VSF}-\mathrm{H}))$ to assess their ability for removing SMZ $(30 \mu \mathrm{g} / \mathrm{L})$ and $\mathrm{TC}(30 \mu \mathrm{g} / \mathrm{L})$ from synthetic swine wastewaters. Their results demonstrated that VSF-L and VSF-H obtained better removal efficiencies for both SMZ (87\% and 70\%) and TC (99\% and 98\%) than SF and HSF systems. This was mainly because the oxygen transfer was greater in the VSFCWs bed than in the others, which enabled VSF-CWs to operate in unsaturated water 
conditions, creating a predominantly aerobic environment (Matamoros et al., 2008; Zhi \& Ji, 2012). In contrast, in HSSF-CWs systems the anaerobic environment prevails because they are continuously fed and the wastewater flows slowly under the surface of the gravel wetland bed. They are also planted with plants which allow them to work in saturated water conditions. As reported earlier, aerobic pathways are generally more efficient for the biodegradation of antibiotics and hormones than anaerobic conditions (Garcia-Rodríguez et al., 2014). Song et al. (2009) confirmed this when they evaluated the removals of estrogens at different sand layer depths $(7.5,30$ and $60 \mathrm{~cm}$ filter layer depth) in VSSF-CWs at the polishing step in conventional wastewater treatment. They found the highest removal efficiencies were achieved in the shallowest wetland $(68 \pm 28 \%, 84 \pm 15 \%$, and $75 \pm 18 \%$ for E1, E2, and EE2, respectively) and concluded that aerobic conditions of the shallowest wetland played a significant role in the highest removal of estrogens.

In constructed wetlands, substrates are essential because they not only provide a basic environment for the growth of plants and microbes, but also remove pollutants from wastewater by adsorption and biodegradation (Wu et al., 2015). However, the contribution of substrates can be influenced by their physical and chemical properties and the characteristics of pollutants. For instance, Sarmah et al. (2006b) indicated the adsorption of antibiotics onto the surface of substrates was affected by hydrophobic partitioning, van der Waals interaction, electrostatic interaction, ion exchange, and surface complexation.

The $\mathrm{pH}$ of substrates could also play an important role in their biosorption capacity due to the different ionization states of antibiotics under different $\mathrm{pH}$ conditions (Conkle et al., 2010; Hussain \& Prasher, 2011). Liu et al. (2014) found red soil $(\mathrm{pH}=4.24)$ showed a higher adsorption level than oyster shell $(\mathrm{pH}=7.67)$ for the removal of $\mathrm{SMZ}$ and $\mathrm{TC}$.

They also indicated substrates with high organic matter surface area and porosity could increase the removal efficiency of antibiotics. This phenomenon is attributed to the 
interaction between the organic groups (carboxyl and phenolic groups), ion exchange, and hydrogen bonding of the substrate matrix with the polar groups of antibiotics (Guan et al., 2017). Different substrates have been studied to compare their removal capacities. Liu et al. (2013) indicated that the zeolite-medium system could remove more ciprofloxacin, OTC, and SMZ than the volcanic-medium system. They concluded it was probably because of the different $\mathrm{pH}$ values and average pore sizes of the respective media.

Huang et al. (2017) operated both mesocosm and microcosm CWs systems to treat wastewater, and their results showed that brick-based columns had stronger OTC and DIF removal than oyster shell-based columns. It is not only due to the larger porosity and average micropore size of brick, but also because of tetracycline and quinolone compounds having complex iron, and easily being adsorbed to iron oxides and iron oxide-rich soils. Thus, the crystalline iron oxide $\left(\mathrm{Fe}_{2} \mathrm{O}_{3}, 32 \%\right)$ in brick should be another important determinant for its higher antibiotic removal capacity.

Based on all of the above, we can see the importance of substrates selection in the CWs system, to date, however, research has only focused on the removal of single classes of antibiotics. Therefore, more studies on the removal of municipal classes of antibiotics should be conducted.

Plants also play a significant role in CWs, although some research indicated that there were no significant differences between the planted and unplanted systems in removing antibiotics (Carvalho et al., 2013). For example, the study by de Carvalho (2012) documented the positive effects of Paustralis-planted beds in CWs for the elimination of veterinary pharmaceuticals from livestock and slaughterhouse industries wastewater. Xian et al. (2010) operated a constructed macrophyte floating bed system with three varieties of Italian ryegrass (Dryan, Tachimasari and Waseyutaka) to compare their removal efficiency of nutrients and veterinary antibiotics from swine wastewater. The finding indicated that 
Dryan performed better than Tachimasari and Waseyutaka. For Dryan, the removal rates of TN, COD, TP and sulfonamide antimicrobials were $84.0 \%, 90.4 \%, 83.4 \%$ and $91.8 \%-99.5 \%$, respectively.

In the CWs system, plants could uptake, transport and metabolize antibiotics through 871 glycosylation and glutathione pathways to eliminate antibiotics (Carvalho et al., 2013). Liu et 872 al. (2013) found all three target antibiotics (CTC, OTC, and SMZ) were detected in the 873 wetland plant leaf during the swine wastewater treatment by CWs, indicating that antibiotics 874 can be removed by wetland pants through mass flow (in transpiration stream) and active 875 uptake. Researchers also detected the removal of antibiotics by plants is correlative with Log 876 Kow, water solubility and the compounds' concentration (Boonsaner \& Hawker, 2010; 877 Dettenmaier et al., 2008; Liu et al., 2013). Compounds with LogKow ranging from 0.5 to 3.5 878 are identified as lipophilic compounds, which could move through the lipid bilayer of plant 879 cell membranes, and they were water soluble enough to travel into the cell fluids of plants ( $\mathrm{Li}$ et al., 2014). A positive correlation between the antibiotics concentrations and the accumulation levels of antibiotics inside the plants is observed (Liu et al., 2013).

In addition, both the secreting oxygen released from plant roots and other productivity, it also affected the activity of microbial and bacterial communities existing in CWs. This could help achieve their optimal activity and produce a beneficial outcome for the removal of antibiotics at warm temperatures in CWs (Truu et al., 2009; Zhang et al., 2011a). Liu et al. (2014) compared the removal rate of SMZ and TC in different seasonal 
conditions $\left(13^{\circ} \mathrm{C}\right.$ in winter and $30^{\circ} \mathrm{C}$ in summer $)$, and concluded that summer conditions had a significantly positive effect on the removal rate of TC and SMZ in CWs.

In order to improve the quality of effluent from CWs system, several hybrid constructed wetlands (hybrid CWs) were developed. They are the combination of two or more wetlands or the combination of wetlands with other pond systems such as lagoons and facultative ponds in parallel or in series ( $\mathrm{Li}$ et al., 2014). It is therefore possible to use the specific advantages of each system. For example, employing a VFCW as a first step would make it possible to nitrify the ammonia species, whereas a HFCW afterwards is able to denitrify the previously produced nitrates (Vymazal, 2013).

However, the major problem associated with CWs processes is land requirements; it is inappropriate in some regions, especially where land resources are scarce and population density is high. Moreover, the performance of CWs largely depends on local climate (Scholz \& Lee, 2005). The high total suspended solid (TSS) load in swine wastewater can also result in progressive clogging occurring near the inlet. As well, the performance of CWs in the start-up period is relatively poor or unstable due to immature rhizosphere environments (Töre et al., 2012). Secondary pollution of groundwater could occur through the leaching of wetlands.

\subsubsection{Modified processes}

To fully remove such refractory toxicants from wastewater, some researchers have tried to modify and improve the conventional aerobic, anaerobic and MBRs processes (shown in Table 6). For example, Zheng et al. (2017) used an intermittently aerated sequencing batch reactor (IASBR) to investigate its removal efficiencies of antibiotics from anaerobically digested swine wastewater. The IASBR system performed better than the conventional SBR system in the removal of TN, $\mathrm{NH}_{3}-\mathrm{N}$ and TOC from swine wastewater (Song et al., 2017b). Under the control of dissolved oxygen (DO), $\mathrm{pH}$, and temperature, the IASBR can create 
alternating aerobic and anoxic environments in each operation cycle to realize partial nitrification and denitrification(Zheng et al., 2017). Zheng et al. (2017) pointed out more than $80 \%$ of all studied antibiotics could be removed by the IASBR system; specifically, $96.2 \%$ of SMs were removed by biodegradation. However, as mentioned in conventional treatment 920 processes, no biodegradation of TC and low removal efficiency (45\%-80\%) of SMZ was 921 observed in conventional SBR processes (Huang et al., 2012; Kim et al., 2005). Similarly, 922 shorter HRT and SRT had a negative relationship with the removal of antibiotics from swine wastewater. Additionally, the author found the removal rate of antibiotics was higher and more stable when influent swine wastewater contained higher concentrations of antibiotics than those in lower ones. This was due to the refractory characteristics of antibiotics and their unfavorable competition against other abundant organics in swine wastewater.

Chen et al. (2017a) indicated conventional wastewater pollutants (BOD5, COD, TN and $\mathrm{NH}_{3}-\mathrm{N}$ ) and nine antibiotics (including SMs and TCs) could be effectively eliminated (85.0$97.2 \%$ and $82.1 \%-100 \%$, respectively) from swine wastewater using a biological aerated filter (BAF) unit in combination with anaerobic and aerobic lagoons. Both aerobic and anaerobic biodegradation contribute to the removal of antibiotics in the BAF system. Compared with the conventional anaerobic and aerobic process, which could not remove SMs effectively (e.g. 0-29.6\%) from swine wastewater, such BAF treatment system shows more advantages (Chen et al., 2012b).

Conventional MBR systems require high alkalinity consumption when treating digested swine wastewater. To reduce such limitations of the MBR on digested swine wastewater 937 treatment, Song et al. (2017c) operated a biofilm MBR (BF-MBR) to remove nutrients and antibiotics from digested swine wastewater and compared their removal rates between the BF-MBR and conventional MBR. The author demonstrated that the BF-MBR performed 940 better than the conventional MBR in the removal of nitrogen, phosphorous and antibiotics. 
941 Compared with $83.8 \%, 57.0 \%$ and $25.5 \%$ of antibiotics removal in the MBR at HRT of $5-4 \mathrm{~d}$, 942 3-2 d and $1 \mathrm{~d}$, respectively, the corresponding values in the BF-MBR could achieve 86.8\%, $94380.2 \%$ and $45.3 \%$. In addition, $40 \%$ less alkalinity was consumed in the BF-MBR system 944 than in the MBR. Song et al. (2017c) also indicated the removal of antibiotics could not only 945 be affected by the HRTs but also the large organic loads, since there was possible 946 competition between biosorption and biodegradation for antibiotics and organic pollutants.

947 The removal efficiency of antibiotics in a two-stage anaerobic fluidized membrane 948 bioreactor (AFMBR) (anaerobic fluidized bed reactor (AFBR) followed by AFMBR) using 949 granular activated carbon (GAC) as the carrier medium in both stages was conducted by 950 Dutta et al. (2014). Their research indicated that all target pharmaceuticals were largely 951 removed in the two-stage AFMBR system and the removal efficiencies were higher in the 952 AFMBR than in the AFBR. Specifically, the overall removal rates of sulfadiazine and SMX 953 were $93.7 \%$ and $89.1 \%$, respectively, and GAC in the first and second stage may play a 954 significant role in removing these pollutants through biosorption. In a full-scale $\mathrm{A}^{2} / \mathrm{O}-\mathrm{MBR}$ 955 process, high removal efficiency $(>70 \%)$ of most of the target compounds was achieved. All 956 the removal rates for E1, E2 and E3 were more than 90\%, and specifically, the stubborn EE2 957 was $97.6 \%$ (Xue et al., 2010), which is largely exceeded the EE2 removal efficiency (80\%) in 958 the conventional $\mathrm{A}^{2} \mathrm{O}$ process as mentioned in activated sludge (AS) processes ( $\mathrm{Li}$ et al., 959 2011).

960 Similar to the above, more than $90 \%$ of the estrogenic hormones can be removed in a 961 fungus-augmented MBR inoculated with a mixed culture of bacteria and white-rot fungi 962 (Wijekoon et al., 2013). The fungus-augmented MBR demonstrated better ability to remove 963 micro-pollutants ( $>80 \%)$ compared with the system containing conventional activated sludge. 964 Biodegradation proved to be the major mechanism for the fungus-augmented MBR, and no 965 toxic by-products were produced (Wijekoon et al., 2013). Compared with basic MBR 
processes, higher removal efficiency (up to 99\%) of antibiotics and estrogenic hormones

967 from synthetic wastewater was achieved in a hybrid MBR with UF, NF and RO (Nguyen et 968 al., 2013).

969 Considering low energy input required for anaerobic technologies, novel anaerobic 970 MBR (AnMBR) systems were gradually established by researchers to study their 971 performance for removing antibiotics and hormones in wastewater (Dutta et al., 2014; Hu et 972 al., 2017; $\mathrm{Hu}$ et al., 2016; Sanchez Huerta, 2016). Hu et al. (2016) investigated the 973 performance of AnMBRs for treating antibiotics polluted wastewater, and indicated more 974 than $90 \%$ of antibiotics were removed mainly through biological processes. Obviously, the 975 degradation capacity of the anaerobic bacteria in AnMBR systems was improved. For 976 example, in comparison with low removal efficiency (31\%) of SMX in the conventional AD 977 process, $95-98 \%$ of SMX was removed by the AnMBR system under optimal conditions after 978 a biomass adaptation period. During the AnMBR process, seven transformation products of 979 SMX were identified and possible degradation pathways were proposed. Moreover, stable biogas composition and methane production were achieved in the experiment (Sanchez Huerta, 2016).

Similarly, Do (2011) operated a novel lab-scale AnMBR system comprising a UASB reactor and dual-flat sheet UF and MF membrane modules to remove E2 and traditional 984 pollutants from landfill leachate. During the stable condition period, the removal efficiency of 985 E2 achieved was around 98\% much higher than that in the individual UASB, which was only 986 23.2\% (Furuichi et al., 2006). However, E2 was still detected in the effluent at average 987 concentrations of $30-40 \mu \mathrm{g} / \mathrm{L}$ range. In that case, powder activated carbon (PAC) was added 988 to the reactor to expand hormone retention and removal by the AnMBR, as well as to control 989 membrane fouling. After the PAC was added, the concentration of E2 was reduced to less 990 than the detection limit (4ng/L) in both MF and UF effluents (Do, 2011). The positive effect 
991 of PAC in MBR systems has been confirmed by other studies. They indicated that adding a 992 low dosage of PAC could improve the critical flux of MBRs, reduce membrane fouling in 993 MBRs and improve MBR sludge filterability at high salinity and low temperature (Remy et 994 al., 2010; Remy et al., 2011; Remy et al., 2009).

995 According to the above review, these modified processes have dominant advantages in 996 removing antibiotics and hormones from wastewater, like high performance and high ability 997 of biodegradation. However, the study of such processes for removing toxicants from swine 998 wastewater is still in its infancy. More research on their removal mechanisms, operational 999 impact factors and challenges need to be evaluated in the future.

1000 Table 6

1001 Removal of target antibiotics and hormones during modified processes

\begin{tabular}{|c|c|c|c|c|c|}
\hline Compounds & $\begin{array}{l}\text { Wastewater } \\
\text { source }\end{array}$ & $\begin{array}{l}\text { Initial } \\
\text { concentrations } \\
(\mu \mathrm{g} / \mathrm{L})\end{array}$ & $\begin{array}{l}\text { Treatment } \\
\text { processes }\end{array}$ & $\begin{array}{l}\text { Removal } \\
\text { efficiencies }\end{array}$ & Reference \\
\hline $\begin{array}{l}\text { Detected } \\
\text { antibiotics }\end{array}$ & $\begin{array}{l}\text { Swine } \\
\text { wastewater }\end{array}$ & 196 & BAF & $>82 \%$ & $\begin{array}{l}\text { (Chen et al., } \\
2017 a)\end{array}$ \\
\hline & $\begin{array}{l}\text { Swine } \\
\text { wastewater }\end{array}$ & l & IASBR & $96.2 \%$ & $\begin{array}{l}\text { (Zheng et } \\
\text { al., 2017) }\end{array}$ \\
\hline SMs & $\begin{array}{l}\text { Digested } \\
\text { swine } \\
\text { wastewater }\end{array}$ & 6.27 & $\begin{array}{l}\text { Lab-scale } \\
\text { BF-MBR }\end{array}$ & $90.3 \%$ & $\begin{array}{l}\text { (Song et al., } \\
2017 \mathrm{c} \text { ) }\end{array}$ \\
\hline SMX & $\begin{array}{l}\text { Municipal } \\
\text { wastewater } \\
\text { Synthetic } \\
\text { wastewater }\end{array}$ & $312 \pm 34.6$ & $\begin{array}{l}\text { Two-stage } \\
\text { AFMBR }\end{array}$ & $89.10 \%$ & $\begin{array}{l}\text { (Dutta et } \\
\text { al., 2014) } \\
\text { (Hu et al., } \\
\text { 2016) }\end{array}$ \\
\hline
\end{tabular}




\begin{tabular}{|c|c|c|c|c|c|}
\hline Sulfadiazin & Municipal & & Two-stage & & (Dutta et \\
\hline 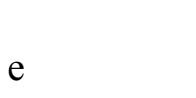 & wastewater & $18.9 \pm 2.1$ & AFMBR & $93.70 \%$ & al., 2014) \\
\hline & $\begin{array}{l}\text { Swine } \\
\text { wastewater }\end{array}$ & l & IASBR & $87.9 \%$ & $\begin{array}{l}\text { (Zheng et } \\
\text { al., 2017) }\end{array}$ \\
\hline TCs & $\begin{array}{l}\text { Digested } \\
\text { swine } \\
\text { wastewater }\end{array}$ & 16.21 & $\begin{array}{l}\text { Lab-scale } \\
\text { BF-MBR }\end{array}$ & $86.8 \%$ & $\begin{array}{l}\text { (Song et al., } \\
2017 \mathrm{c} \text { ) }\end{array}$ \\
\hline $\mathrm{TC}$ & $\begin{array}{l}\text { Digested } \\
\text { swine } \\
\text { wastewater }\end{array}$ & 3.83 & $\begin{array}{l}\text { Lab-scale } \\
\text { BF-MBR }\end{array}$ & $81.7 \%$ & $\begin{array}{l}\text { (Song et al., } \\
\text { 2017c) }\end{array}$ \\
\hline OTC & $\begin{array}{l}\text { Digested } \\
\text { swine } \\
\text { wastewater }\end{array}$ & 0.67 & $\begin{array}{l}\text { Lab-scale } \\
\text { BF-MBR }\end{array}$ & $88.1 \%$ & $\begin{array}{l}\text { (Song et al., } \\
2017 \mathrm{c} \text { ) }\end{array}$ \\
\hline CTC & $\begin{array}{l}\text { Digested } \\
\text { swine } \\
\text { wastewater }\end{array}$ & 0.35 & $\begin{array}{l}\text { Lab-scale } \\
\text { BF-MBR }\end{array}$ & $71.4 \%$ & $\begin{array}{l}\text { (Song et al., } \\
2017 \mathrm{c} \text { ) }\end{array}$ \\
\hline $\mathrm{DC}$ & $\begin{array}{l}\text { Digested } \\
\text { swine } \\
\text { wastewater }\end{array}$ & 11.36 & $\begin{array}{l}\text { Lab-scale } \\
\text { BF-MBR }\end{array}$ & $88.9 \%$ & $\begin{array}{l}\text { (Song et al., } \\
2017 \mathrm{c} \text { ) }\end{array}$ \\
\hline & $\begin{array}{l}\text { Synthetic } \\
\text { wastewater }\end{array}$ & 0.13 & $\begin{array}{l}\text { Full-scale } \\
\text { A2/O-MBR }\end{array}$ & $>90 \%$ & $\begin{array}{l}\text { (Xue et al., } \\
\text { 2010) }\end{array}$ \\
\hline E1 & $\begin{array}{l}\text { Synthetic } \\
\text { wastewater }\end{array}$ & 5 & $\begin{array}{l}\text { Lab-scale } \\
\text { MBR- } \\
\text { UF/NF/RO }\end{array}$ & $\begin{array}{l}99.30 \%- \\
99.6 \%\end{array}$ & $\begin{array}{l}\text { (Nguyen et } \\
\text { al., 2013) }\end{array}$ \\
\hline
\end{tabular}




\begin{tabular}{|c|c|c|c|c|c|}
\hline & & & Fungus- & & \\
\hline & Synthetic & & & & (Wijekoon \\
\hline & & / & augmented & $>90 \%$ & \\
\hline & wastewater & & MBR & & et al., 2013) \\
\hline & Synthetic & & Full-scale & & (Xue et al., \\
\hline & & $0.043 \pm 0.12$ & & $>90 \%$ & \\
\hline & wastewater & & A2/O-MBR & & 2010) \\
\hline & Landfill & & & & \\
\hline E2 & & l & AnMBR & $98 \%$ & $(\mathrm{Do}, 2011)$ \\
\hline & leachate & & & & \\
\hline & & & Lab-scale & & \\
\hline & Synthetic & & & $99.4 \%$ - & (Nguyen et \\
\hline & & 5 & MBR- & $\operatorname{sen}$ & 2010) \\
\hline & wastewater & & UF/NF/RO & $99.60 \%$ & al., 2013) \\
\hline & Synthetic & & Full-scale & & (Xue et al., \\
\hline & & $0.14 \pm 0.07$ & & $>90 \%$ & \\
\hline & wastewater & & A2/O-MBR & & 2010) \\
\hline & Landfill & & $\mathrm{AnMBR}+\mathrm{PA}$ & & \\
\hline & & l & & $100 \%$ & (Do, 2011) \\
\hline & leachate & & $\mathrm{C}$ & & \\
\hline & & & Lab-scale & & \\
\hline E3 & Synthetic & & & $96.1 \%-$ & (Nguyen et \\
\hline & wastewater & 5 & & $0830 \%$ & al 2013) \\
\hline & & & $\mathrm{UF} / \mathrm{NF} / \mathrm{RO}$ & & \\
\hline & & & Fungus- & & \\
\hline & Synthetic & & & & (Wijekoon \\
\hline & & l & augmented & $>90 \%$ & \\
\hline & wastewater & & & & et al., 2013) \\
\hline & & & MBR & & \\
\hline & Synthetic & & Full-scale & & (Xue et al., \\
\hline & & $0.16 \pm 0.25$ & & $97.60 \%$ & \\
\hline & wastewater & & $\mathrm{A}^{2} / \mathrm{O}-\mathrm{MBR}$ & & 2010) \\
\hline EE2 & & & Lab-scale & & \\
\hline & Synthetic & & & $93.60 \%$ - & (Nguyen et \\
\hline & & 5 & MBR- & & \\
\hline & wastewater & & & $95.5 \%$ & al., 2013) \\
\hline & & & UF/NF/RO & & \\
\hline
\end{tabular}


1002

1003

1004

1005

1006

1007

1008

1009

1010

1011

1012

1013

1014

1015

1016

1017

1018

1019

1020

1021

1022

1023

1024

1025

\section{Comparison of different bioprocesses}

Table 7 compares the removal efficiencies of target antibiotics and hormones in different bioprocesses. Conventional treatment processes like AS and AD are widely used to eliminate traditional pollutants (e.g. COD, BOD and TN) from swine wastewater (Chen et al., 2012b; Zhang et al., 2006).

Yet, as shown in Table 7, their removal efficiencies for antibiotics and hormones are limited compared those in advanced treatment processes. Large fluctuations of the removal efficiencies of antibiotics and hormones in AS and AD processes were observed according to different operating conditions (e.g. HRT, SRT, $\mathrm{pH}$ and temperature). For example, in the optimum operating conditions, like prolonging HRT and SRT in tests, a high removal efficiency $(>80 \%$ ) could be achieved in conventional AS processes (Kim et al., 2005; Yang et al., 2012). However, it is obvious that operating costs for per unit volume of wastewater will definitely increase for extending HRT and/or SRT in wastewater treatment plants, besides, unlike in MBRs processes, HRT and SRT cannot be separated completely in conventional AS processes. According to the real conditions, the common values of SRT in conventional activated sludge systems are 3-8 d. It is not enough for the growth of antibiotics biodegrading bacterium, meaning that target antibiotics cannot be well biodegraded in the conventional AS process (Ben et al., 2014). It has been confirmed by the removal of TC and tylosin from swine wastewater, that their biodegradation efficiencies were $-28 \%$ to $-35 \%$ and $4 \%$ to $-5 \%$, respectively (Prado et al., 2009a). Thus, biosorption removal plays a significant role in conventional treatment processes, which entails large amounts of antibiotics and hormones remaining in the excess sludge. In this case, large amounts of money and labour should be poured into sludge treatment, otherwise, secondary pollution will occur after being applied to land. 
1026 Conversely, such drawbacks in conventional AS processes can be solved in MBRs 1027 processes, in which SRT and HRT can be increased independently (De Cazes et al., 2014b).

1028 Therefore the removal of antibiotics and hormones by biodegradation can be largely 1029 improved in MBRs. For example, 83.8\% of 11 typical veterinary antibiotics could be 1030 removed from digested swine wastewater in the MBR and removal through biodegradation 1031 was the dominant mechanism (Song et al., 2017c). For most target toxicants, high and stable 1032 removal efficiencies (45.7\%-99\%) are obtained in MBRs processes, especially in modified or 1033 hybrid MBR processes (71.4\%-100\%). Although the MBRs can also be influenced by the 1034 operating conditions, it is easy for MBRs to situate themselves in an ideal state. However, 1035 given that many of the world's economy is now conscious about saving energy and resources, 1036 energy dissipation and membrane fouling in conventional MBRs are the biggest challenges, 1037 which costs lots of energy and money on aeration and membrane cleaning/replacement.

1038 As an energy-efficient and environmentally friendly technology, AD processes are 1039 commonly used for treating wastewater originating from livestock farms. However, they are 1040 not efficient for treating high-strength and toxicant swine wastewater. As stated previously, 1041 the biodegradable removal of toxicants in anaerobic conditions is less efficient than in 1042 aerobic conditions, possibly due to the toxicity of antibiotics. For the hard adsorption removal 1043 compounds, SMs, only 8.3\%-31\% were removed from swine wastewater in the AD process, 1044 and the total removal efficiency for estrogenic hormones amounted to only $21.8 \%$. The 1045 AnMBR process is a good alternative to the conventional AD processes and aerobic MBR 1046 process as relatively low energy consumed and highly improved degradation capacity of the 1047 anaerobic bacteria in such a process. In contrast, 95-98\% of SMX was removed from 1048 synthetic wastewater via the AnMBR system under optimal conditions and after the biomass 1049 adaptation period. 
However, the fluxes in AnMBRs tend to be less than those of aerobic MBRs, and 1051 membrane-fouling problems still exist. The addition of PAC to AnMBR processes not only 1052 can improve the critical flux of MBRs and reduce membrane fouling, but also can increase 1053 the removal efficiency of toxicants (Do, 2011). However, combined with other modified 1054 processes, these promising technologies are not yet applied in removing antibiotic and 1055 hormones from swine wastewater, which deserve to be fully discussed in the future.

1056 Compared with the above market technologies, several authors reported that CWs 1057 processes are promising treatment technologies for removing antibiotics and hormones from 1058 swine wastewater because of their low cost, simple operation and high performance in 1059 removing conventional and toxic pollutants and pathogens. Choosing suitable substrate, 1060 plants, and CWs types is important for the proper functioning of CWs processes. VSSF-CWs 1061 systems were regarded as the most efficient systems among three types of CWs. The high 1062 removal rate $(>70 \%)$ of initially large concentrations of antibiotics can be obtained in such 1063 systems. Substrates, like red soil, zeolite, and brick were reported as being more suitable for 1064 the removal of antibiotics than oyster shell and volcanic rock. However, most research 1065 focused only on single classes of antibiotics, so further studies about their function on 1066 municipal classes of antibiotics and hormones should be conducted.

1067 In addition, drawbacks associated with CWs processes, such as large land requirements, 1068 high dependence on local climate and secondary pollution to groundwater cannot be 1069 neglected. Besides these issues, clogging may also occur near the inlet due to the high total 1070 suspended solid (TSS) load in swine wastewater. 
Comparison of target antibiotics and hormones removal from different bioprocesses

\begin{tabular}{|c|c|c|c|}
\hline Bioprocesses & Removal rate & Advantages & Disadvantages \\
\hline AS & $\begin{array}{l}\text { SMs: } 0-92.1 \% \\
\text { TCs: }-35 \%-100 \% \\
\text { Tylosin: }-5 \%-4 \% \\
\text { Hormones: } 80 \%-99.9 \%\end{array}$ & $\begin{array}{l}\text { 1. Most widely used technology, 2. High } \\
\text { organic removal efficiency }\end{array}$ & $\begin{array}{l}\text { 1. The biodegradability for antibiotics and } \\
\text { hormones is not sufficient, } 2 \text {. The removal is } \\
\text { mainly through adsorption onto sludge, } 3 \text {. The } \\
\text { outcome is secondary pollution, } 4 \text {. Polishing } \\
\text { treatment is needed }\end{array}$ \\
\hline $\mathrm{AD}$ & $\begin{array}{l}\text { SMs: } 8.3 \%-31 \% \\
\text { TCs: } 14.97 \%-98.2 \% \\
\text { Tylosin: } 75 \%-99 \% \\
\text { Hormones: } 19 \%-81 \%\end{array}$ & $\begin{array}{l}\text { 1. Energy investment is low, } 2 \text {. Less sludge } \\
\text { production, 3. Generating biogas }\end{array}$ & $\begin{array}{l}\text { 1. The biodegradability of antibiotics and } \\
\text { hormones is low, } 2 \text {. High concentrations of } \\
\text { toxicants were detected in the effluent, } 3 \text {. They } \\
\text { still pose a serious risk to the environment }\end{array}$ \\
\hline MBRs & $\begin{array}{l}\text { SMs: } 80 \%-87.4 \% \\
\text { TCs: } 45.7 \%-94 \% \\
\text { Hormones: } 94.5 \%-99 \%\end{array}$ & $\begin{array}{l}\text { 1. Long SRT, 2. Flexibility in operation, } 3 \text {. } \\
\text { Compact plant structure, } 4 \text {. Minimal sludge } \\
\text { production, } 5 \text {. High biodegradability, } 6 \text {. High } \\
\text { biomass diversity, } 7 \text {. Stable and excellent } \\
\text { effluent quality, } 8 \text {. Less affected by the } \\
\text { toxicity of antibiotics. }\end{array}$ & $\begin{array}{l}\text { 1. High energy requirement in conventional } \\
\text { MBRs, } 2 \text {. Fouling and clogging of the } \\
\text { membrane, } 3 \text {. High costs }\end{array}$ \\
\hline CWs & $\begin{array}{l}\text { SMs: } 40 \%-87 \% \\
\text { TCs: } 90 \%-97 \% \\
\text { Hormones: } 31.8 \%-95.2 \%\end{array}$ & $\begin{array}{l}\text { 1. Low cost, 2. Simple construction and } \\
\text { operation, } 3 \text {. High performance for removal } \\
\text { of conventional and toxic pollutants and } \\
\text { pathogens }\end{array}$ & $\begin{array}{l}\text { 1. Large land requirements, } 2 \text {. Highly dependent } \\
\text { on local climate, } 3 \text {. The high total suspended } \\
\text { solid (TSS) load in swine wastewater can result } \\
\text { in the progressive clogging that occurs near the } \\
\text { inlet, } 4 \text {. Low or unstable performance in the } \\
\text { start-up period } 5 \text {. Secondary pollution of }\end{array}$ \\
\hline
\end{tabular}


IASBR: Better performance than conventional SBR;

SMs: $89.1 \%-98 \%$

\section{Modified}

processes

TCs: $71.4 \%-88.9 \%$

Hormones: 90\%-99.6\%

by-products were produced;
Fungus-augmented MBR: 1. Biodegradation

is proved the major mechanism, 2. No toxic

MBR-NF/RO: Excellent effluent quality;

Including advantages in MBR, AnMBR: 1.

Degradation capacity of the anaerobic

bacteria is improved, 2. Stable biogas composition and methane production;

AnMBR + PAC: 1.PAC could improve the critical flux of MBRs, 2 . Reducing membrane fouling in MBRs. 3 Improving MBR sludge

filterability at high salinity and low

temperature.
Modified processes still need more studies in future. 
1073

1074

1075

1076

1077

1078

1079

1080

1081

1082

1083

1084

1085

1086

1087

1088

1089

1090

1091

1092

1093

1094

1095

1096

1097

\section{Future perspectives}

The risk of residual antibiotics and hormones in the environment has generated global concerns and this risk will continue due to the endless use of veterinary medicines on pigs. There are furthermore still no clear guidelines for utilizing veterinary medicines and management of swine wastewater treatment. Governments must establish the guidelines and discharge standards as soon as possible.

In biological treatment processes, biosorption and biodegradation simultaneously contributed to the removal of antibiotics and hormones from swine wastewater. However, for different classes of antibiotics and hormones, the contributions of biosorption and biodegradation vary. It is closely related to their own physicochemical characteristics, operating conditions, adopted technologies, etc. Other studies have not clearly demonstrated the ratios of antibiotics and hormones removed by biosorption and biodegradation. The toxicants removed by biosorption still remain in the sludge, and can cause secondary pollution after sludge enter the environment. In order to decrease such secondary pollution, more studies are urgently required to clarify the contribution of biosorption and biodegradation, respectively.

In addition, as the most important removal mechanism of toxicants, the specific degradation pathways and intermediates of biodegradation should be fully investigated in the future. As mentioned above, only a small fraction of antibiotics and hormones was completely oxidized into water and carbon dioxide. The majority of them were simply transformed into intermediates. Some research has reported that such intermediates are more harmful than their original forms. In order to improve the removal of toxicants from wastewater, the role and function of microorganisms in bioprocesses should also be considered. Although some forms of bacteria have been isolated from activated sludge, they merely act on individual classes of toxicants. Consequently, in-depth investigations must be 
conducted to find what kinds of microorganisms are responsible for the removal of antibiotics and hormones. This is particularly important given that toxicants have different physicochemical properties and biodegradability.

To better compare the performance of different treatment processes, more standardized and reliable methods for the quantification of antibiotics and hormones need to be conducted in the future. Through the above review and comparison, MBRs processes are the most efficient technologies for removing antibiotics and hormones from wastewater, but most current studies have focused only on synthetic wastewater or municipal wastewater. Their performance on swine wastewater requires much more analysis. Furthermore, current bioprocessing mainly operates under lab-scale conditions, and full-scale operation has to be taken into account since the efficiency of the process is highly influenced by the operating conditions.

\section{Conclusion}

Swine wastewater has become a major pollution source of antibiotics and hormones because of the huge demand for pork and the high extraction rate through swine manure and urine. In biological treatment processes, such micro-pollutants are mainly removed through biosorption and biodegradation, and biodegradation is the most important mechanism while biosorption is only the initial step. The physicochemical characteristics of various antibiotics and hormones correlate with their degradation profile. TCs and estrogenic hormones are relatively easily absorbed on activated sludge through electrostatic interactions and hydrophobic interactions. In contrast, SMs were mainly removed by biodegradation because of their $\operatorname{low} \operatorname{logKow}$ value $(\operatorname{logKow}<2)$ and less electrostatic interaction with the activated sludge's negatively charged surface.

Co-metabolism by microorganisms is the major pathway for the biodegradation of antibiotics and hormones. Some microorganism strains have been isolated from sludge for the 
1123 biodegradation of antibiotics and hormones. Conventional treatment processes are never 1124 complete and biosorption is the major removal pathway for most antibiotics and hormones, 1125 which means that large amounts of toxicants remain in the sludge. With particular reference

1126 to AD processes, the biodegradability of anaerobic bacteria needs to be improved. Although 1127 CWs processes do have several advantages and are more efficient than conventional 1128 treatment processes, their limits and drawbacks for wide application must be recognized. 1129 MBRs, the most promising technology, demonstrate much better performance and 1130 practicability than other technologies. Conversely, the membrane fouling, energy 1131 consumption and cost in conventional MBRs have to be considered. Therefore, the modified 1132 processes are considered as promising technologies, which have to be studied in the future. 1133 Acknowledgments

1134 This review research was supported by the Centre for Technology in Water and Wastewater, 1135 School of Civil and Environmental Engineering, University of Technology, Sydney (UTS) 1136 and Joint Research Centre for Protective Infrastructure Technology and Environmental Green 1137 Bioprocess (UTS and Tianjin Chengjian University). The authors are also grateful to the 1138 research collaboration among UTS, Kyonggi University, Ho Chi Minh City University of 1139 Technology and Duy Tan University.

\section{References}

1142 Aad, G., Abajyan, T., Abbott, B., Abdallah, J., Khalek, S.A., Abdelalim, A., Abdinov, O., Aben, R., Abi, B., Abolins, M. 2012. Observation of a new particle in the search for the Standard Model Higgs boson with the ATLAS detector at the LHC. Phys. Lett. B, 716(1), 1-29. 
Abegglen, C., Joss, A., McArdell, C.S., Fink, G., Schlüsener, M.P., Ternes, T.A., Siegrist, H. 2009. The fate of selected micropollutants in a single-house MBR. Water Res., 43(7), 2036-2046.

Adeel, M., Song, X., Wang, Y., Francis, D., Yang, Y. 2017. Environmental impact of estrogens on human, animal and plant life: a critical review. Environ. Int., 99, 107119.

Álvarez, J.A., Otero, L., Lema, J.M., Omil, F. 2010. The effect and fate of antibiotics during the anaerobic digestion of pig manure. Bioresour. Technol., 101(22), 8581-8586.

Alvarino, T., Suarez, S., Lema, J.M., Omil, F. 2014. Understanding the removal mechanisms of PPCPs and the influence of main technological parameters in anaerobic UASB and aerobic CAS reactors. J. Hazard. Mater., 278, 506-513.

Amin, M.M., Bina, B., Ebrahim, K., Yavari, Z., Mohammadi, F. 2017. Biodegradation of natural and synthetic estrogens in moving bed bioreactor. Chin. J. Chem. Eng.

Angelidaki, I., Ellegaard, L., Ahring, B.K. 2003. Applications of the anaerobic digestion process. in: Biomethanation II, Springer, pp. 1-33.

Angenent, L.T., Mau, M., George, U., Zahn, J.A., Raskin, L. 2008. Effect of the presence of the antimicrobial tylosin in swine waste on anaerobic treatment. Water Res., 42(10), $2377-2384$.

Baguer, A.J., Jensen, J., Krogh, P.H. 2000. Effects of the antibiotics oxytetracycline and tylosin on soil fauna. Chemosphere, 40(7), 751-757.

Bais, H.P., Weir, T.L., Perry, L.G., Gilroy, S., Vivanco, J.M. 2006. The role of root exudates in rhizosphere interactions with plants and other organisms. Annu. Rev. Plant Biol., 57, 233-266. 
Banihashemi, B., Droste, R.L. 2014. Sorption-desorption and biosorption of bisphenol A, triclosan, and 17 $\alpha$-ethinylestradiol to sewage sludge. Sci. Total Environ., 487, 813821.

Baquero, F., Martínez, J.-L., Cantón, R. 2008. Antibiotics and antibiotic resistance in water environments. Curr. Opin. Biotechnol., 19(3), 260-265.

Barber, W.P., Stuckey, D.C. 1999. The use of the anaerobic baffled reactor (ABR) for wastewater treatment: a review. Water Res., 33(7), 1559-1578.

Becerra-Castro, C., Lopes, A.R., Vaz-Moreira, I., Silva, E.F., Manaia, C.M., Nunes, O.C. 2015. Wastewater reuse in irrigation: a microbiological perspective on implications in soil fertility and human and environmental health. Environ. Int., 75, 117-135.

Ben, W., Pan, X., Qiang, Z. 2013. Occurrence and partition of antibiotics in the liquid and solid phases of swine wastewater from concentrated animal feeding operations in Shandong Province, China. Environ. Sci. Process. Impact., 15(4), 870-875.

Ben, W., Qiang, Z., Pan, X., Chen, M. 2009. Removal of veterinary antibiotics from sequencing batch reactor (SBR) pretreated swine wastewater by Fenton's reagent. Water Res., 43(17), 4392-4402.

Ben, W., Qiang, Z., Pan, X., Nie, Y. 2011. Degradation of veterinary antibiotics by ozone in swine wastewater pretreated with sequencing batch reactor. J. Environ. Eng., 138(3), $272-277$.

Ben, W., Qiang, Z., Yin, X., Qu, J., Pan, X. 2014. Adsorption behavior of sulfamethazine in an activated sludge process treating swine wastewater. J. Environ. Sci., 26(8), 16231629.

Ben, W.W., Qiang, Z.M., Adams, C., Zhang, H.Q., Chen, L.P. 2008. Simultaneous determination of sulfonamides, tetracyclines and tiamulin in swine wastewater by 
solid-phase extraction and liquid chromatography-mass spectrometry. J. Chromatogr., 1202(2), 173-180.

Ben, W.W., Wang, J., Pan, X., Qiang, Z.M. 2017. Dissemination of antibiotic resistance genes and their potential removal by on-farm treatment processes in nine swine feedlots in Shandong Province, China. Chemosphere, 167, 262-268.

Boonsaner, M., Hawker, D.W. 2010. Accumulation of oxytetracycline and norfloxacin from saline soil by soybeans. Sci. Total Environ., 408(7), 1731-1737.

Cajthaml, T., Křesinová, Z., Svobodová, K., Sigler, K., Řezanka, T. 2009. Microbial transformation of synthetic estrogen 17 $\alpha$-ethinylestradiol. Environ. Pollut., 157(12), $3325-3335$.

Campagnolo, E.R., Johnson, K.R., Karpati, A., Rubin, C.S., Kolpin, D.W., Meyer, M.T., Esteban, J.E., Currier, R.W., Smith, K., Thu, K.M. 2002. Antimicrobial residues in animal waste and water resources proximal to large-scale swine and poultry feeding operations. Sci. Total Environ., 299(1), 89-95.

Carballa, M., Omil, F., Ternes, T., Lema, J.M. 2007. Fate of pharmaceutical and personal care products (PPCPs) during anaerobic digestion of sewage sludge. Water Res., 41(10), 2139-2150.

Carvalho, P.N., Araújo, J.L., Mucha, A.P., Basto, M.C.P., Almeida, C.M.R. 2013. Potential of constructed wetlands microcosms for the removal of veterinary pharmaceuticals from livestock wastewater. Bioresour. Technol., 134, 412-416.

Castanon, J. 2007. History of the use of antibiotic as growth promoters in European poultry feeds. Poult Sci, 86(11), 2466-2471.

Chang, B.V., Hsu, F.Y., Liao, H.Y. 2014. Biodegradation of three tetracyclines in swine wastewater. J. Environ. Sci. Health. B., 49(6), 449-455. 
1217 Chelliapan, S., Wilby, T., Sallis, P.J. 2006. Performance of an up-flow anaerobic stage

1218

1219

1220

1221

1222

1223

1224

1225

1226

1227

1228

1229

1230

1231

1232

1233

1234

1235

1236

1237

1238

1239

1240

reactor (UASR) in the treatment of pharmaceutical wastewater containing macrolide antibiotics. Water Res., 40(3), 507-516.

Chen, J., Liu, Y.S., Zhang, J.N., Yang, Y.Q., Hu, L.X., Yang, Y.Y., Zhao, J.L., Chen, F.R., Ying, G.G. 2017a. Removal of antibiotics from piggery wastewater by biological aerated filter system: Treatment efficiency and biodegradation kinetics. Bioresour. Technol., 238, 70-77.

Chen, J., Michel, F.C., Jr., Sreevatsan, S., Morrison, M., Yu, Z. 2010. Occurrence and persistence of erythromycin resistance genes (erm) and tetracycline resistance genes (tet) in waste treatment systems on swine farms. Microb. Ecol., 60(3), 479-86.

Chen, M.X., Qi, R., An, W., Zhang, H.Q., Wei, Y.S., Zhou, Y.Q. 2009. New concept of contaminant removal from swine wastewater by a biological treatment process. Front. Biol. (Beijing), 4(4), 402.

Chen, Q.Q., Wu, W.D., Zhang, Z.Z., Xu, J.J., Jin, R.C. 2017b. Inhibitory effects of sulfamethoxazole on denitrifying granule properties: Short- and long-term tests. Bioresour. Technol., 233, 391-398.

Chen, Y., Cheng, J.J., Creamer, K.S. 2008. Inhibition of anaerobic digestion process: a review. Bioresour. Technol., 99(10), 4044-4064.

Chen, Y., Zhang, H., Luo, Y., Song, J. 2012a. Occurrence and assessment of veterinary antibiotics in swine manures: a case study in East China. Chin. Sci. Bull., 57(6), 606614.

Chen, Y., Zhang, H., Luo, Y., Song, J. 2012b. Occurrence and dissipation of veterinary antibiotics in two typical swine wastewater treatment systems in east China. Environ. Model. Assess., 184(4), 2205-2217. 
1241 Chen, Y.S., Zhang, H.B., Luo, Y.M., Song, J. 2012c. Occurrence and dissipation of

1242

1243

1244

1245

1246

1247

1248

1249

1250

1251

1252

1253

1254

1255

1256

1257

1258

1259

1260

1261

1262

1263

1264

veterinary antibiotics in two typical swine wastewater treatment systems in east China. Environ. Monit. Assess., 184(4), 2205-2217.

Cheng, J., Liu, B. 2002. Swine wastewater treatment in anaerobic digesters with floating medium. Trans. ASAE, 45(3), 799-805.

Choi, K.J., Kim, S.G., Kim, S.H. 2008. Removal of antibiotics by coagulation and granular activated carbon filtration. J. Hazard. Mater., 151(1), 38-43.

Cirja, M., Ivashechkin, P., Schäffer, A., Corvini, P.F. 2008. Factors affecting the removal of organic micropollutants from wastewater in conventional treatment plants (CTP) and membrane bioreactors (MBR). Rev. Environ. Sci. Bio., 7(1), 61-78.

Clara, M., Strenn, B., Saracevic, E., Kreuzinger, N. 2004. Adsorption of bisphenol-A, 17ßestradiole and 17 $\alpha$-ethinylestradiole to sewage sludge. Chemosphere, 56(9), 843-851.

Clouzot, L., Doumenq, P., Vanloot, P., Roche, N., Marrot, B. 2010. Membrane bioreactors for 17 $\alpha$-ethinylestradiol removal. J. Membr. Sci., 362(1), 81-85.

Combalbert, S., Bellet, V., Dabert, P., Bernet, N., Balaguer, P., Hernandez-Raquet, G. 2012. Fate of steroid hormones and endocrine activities in swine manure disposal and treatment facilities. Water Res., 46(3), 895-906.

Combalbert, S., Hernandez-Raquet, G. 2010. Occurrence, fate, and biodegradation of estrogens in sewage and manure. Appl. Microbiol. Biotechnol., 86(6), 1671-92.

Conkle, J.L., Lattao, C., White, J.R., Cook, R.L. 2010. Competitive sorption and desorption behavior for three fluoroquinolone antibiotics in a wastewater treatment wetland soil. Chemosphere, 80(11), 1353-1359.

Córdoba, V., Fernández, M., Santalla, E. 2016. The effect of different inoculums on anaerobic digestion of swine wastewater. J. Environ. Chem. Eng., 4(1), 115-122. 
Czajka, C.P., Londry, K.L. 2006. Anaerobic biotransformation of estrogens. Sci. Total Environ., 367(2), 932-941.

de Carvalho, P.N. 2012. Implementation of methodologies for removal of veterinary pharmaceuticals residues from WWTPs effluents of the livestock industry[PhD]. University of Porto, Porto.

de Cazes, M., Abejón, R., Belleville, M.P., Sanchez-Marcano, J. 2014a. Membrane bioprocesses for pharmaceutical micropollutant removal from waters. Membr., 4(4), $692-729$.

De Cazes, M., Belleville, M.P., Petit, E., Llorca, M., Rodríguez-Mozaz, S., De Gunzburg, J., Barceló, D., Sanchez-Marcano, J. 2014b. Design and optimization of an enzymatic membrane reactor for tetracycline degradation. Catal. Today, 236, 146-152.

De Gusseme, B., Pycke, B., Hennebel, T., Marcoen, A., Vlaeminck, S.E., Noppe, H., Boon, N., Verstraete, W. 2009. Biological removal of $17 \alpha$-ethinylestradiol by a nitrifier enrichment culture in a membrane bioreactor. Water Res., 43(9), 2493-2503.

De Mes, T., Kujawa-Roeleveld, K., Zeeman, G., Lettinga, G. 2008. Anaerobic biodegradation of estrogens — hard to digest. Water Sci. Technol., 57(8), 1177-1182.

De Wever, H., Weiss, S., Reemtsma, T., Vereecken, J., Müller, J., Knepper, T., Rörden, O., Gonzalez, S., Barcelo, D., Hernando, M.D. 2007. Comparison of sulfonated and other micropollutants removal in membrane bioreactor and conventional wastewater treatment. Water Res., 41(4), 935-945.

Deksissa, T. 2008. Fate and transport of steroid hormones in the environment.

Deng, L.W., Zheng, P., Chen, Z.A. 2006. Anaerobic digestion and post-treatment of swine wastewater using IC-SBR process with bypass of raw wastewater. Process Biochem., 41(4), 965-969. 
Dettenmaier, E.M., Doucette, W.J., Bugbee, B. 2008. Chemical hydrophobicity and uptake by plant roots. Environ. Sci. Technol., 43(2), 324-329.

Do, A.T. 2011. Anaerobic Membrane Bioreactor (AnMBR) for Treatment of Landfill Leachate and Removal of Micropollutants[PhD]. University of South Florida.

Dreher, T.M., Mott, H.V., Lupo, C.D., Oswald, A.S., Clay, S.A., Stone, J.J. 2012. Effects of chlortetracycline amended feed on anaerobic sequencing batch reactor performance of swine manure digestion. Bioresour. Technol., 125, 65-74.

Du, L.F., Liu, W.K. 2012. Occurrence, fate, and ecotoxicity of antibiotics in agro-ecosystems. A review. Agron. Sustain. Dev., 32(2), 309-327.

Dutta, K., Lee, M.Y., Lai, W.W.P., Lee, C.H., Lin, A.Y.C., Lin, C.F., Lin, J.G. 2014. Removal of pharmaceuticals and organic matter from municipal wastewater using two-stage anaerobic fluidized membrane bioreactor. Bioresour. Technol., 165, 42-49.

Dytczak, M., Londry, K., Oleszkiewicz, J. 2008. Biotransformation of estrogens in nitrifying activated sludge under aerobic and alternating anoxic/aerobic conditions. Water Environ. Res., 80(1), 47-52.

Ebele, A.J., Abou-Elwafa Abdallah, M., Harrad, S. 2017. Pharmaceuticals and personal care products (PPCPs) in the freshwater aquatic environment. Emerg. Contam., 3(1), 1-16.

Fischer, K., Majewsky, M. 2014. Cometabolic degradation of organic wastewater micropollutants by activated sludge and sludge-inherent microorganisms. Appl. Microbiol. Biotechnol., 98(15), 6583-6597.

Furuichi, T., Kannan, K., Suzuki, K., Tanaka, S., Giesy, J.P., Masunaga, S. 2006. Occurrence of estrogenic compounds in and removal by a swine farm waste treatment plant. Environ. Sci. Technol., 40(24), 7896-7902. 
1312

1313

1314

1315

1316

1317

1318

1319

1320

1321

1322

1323

1324

1325

1326

1327

1328

1329

1330

1331

1332

1333

1334

1335

Galán, M.J.G., Díaz-Cruz, M.S., Barceló, D. 2012. Removal of sulfonamide antibiotics upon conventional activated sludge and advanced membrane bioreactor treatment. Anal. Bioanal. Chem., 404(5), 1505-1515.

Ganiyu, S.O., van Hullebusch, E.D., Cretin, M., Esposito, G., Oturan, M.A. 2015. Coupling of membrane filtration and advanced oxidation processes for removal of pharmaceutical residues: A critical review. Sep. Purif. Technol., 156, Part 3, 891-914.

Gao, P., He, S., Huang, S., Li, K., Liu, Z., Xue, G., Sun, W. 2015. Impacts of coexisting antibiotics, antibacterial residues, and heavy metals on the occurrence of erythromycin resistance genes in urban wastewater. Appl. Microbiol. Biotechnol., 99(9), 3971-3980.

Gao, P., Munir, M., Xagoraraki, I. 2012. Correlation of tetracycline and sulfonamide antibiotics with corresponding resistance genes and resistant bacteria in a conventional municipal wastewater treatment plant. Sci. Total Environ., 421, 173-183.

Garcia-Rodríguez, A., Matamoros, V., Fontàs, C., Salvadó, V. 2014. The ability of biologically based wastewater treatment systems to remove emerging organic contaminants - a review. Environ. Sci. Pollut. Res., 21(20), 11708-11728.

García-Sánchez, L., Garzón-Zúñiga, M.A., Buelna, G., Estrada-Arriaga, E.B. 2016. Tylosin effect on methanogenesis in an anaerobic biomass from swine wastewater treatment. Water Sci. Technol., 73(2), 445-452.

García-Sánchez, L., Garzón-Zúñiga, M.A., Buelna, G., Moeller-Chávez, G.E., Noyola, A., Avilez-Flores, M., Estrada-Arriaga, E.B. 2013. Occurrence of tylosin in swine wastewater in Mexico. Water Sci. Technol., 68(4), 894-900.

Gartiser, S., Urich, E., Alexy, R., Kümmerer, K. 2007. Anaerobic inhibition and biodegradation of antibiotics in ISO test schemes. Chemosphere, 66(10), 1839-1848. 
Göbel, A., McArdell, C.S., Joss, A., Siegrist, H., Giger, W. 2007. Fate of sulfonamides, macrolides, and trimethoprim in different wastewater treatment technologies. Sci. Total Environ., 372(2), 361-371.

Gonzalez Ronquillo, M., Angeles Hernandez, J.C. 2017. Antibiotic and synthetic growth promoters in animal diets: Review of impact and analytical methods. Food Control.

Guan, Y.D., Wang, B., Gao, Y.X., Liu, W., Zhao, X.L., Huang, X.F., Yu, J.H. 2017. Occurrence and Fate of Antibiotics in the Aqueous Environment and Their Removal by Constructed Wetlands in China: A review. Pedosphere, 27(1), 42-51.

Gulkowska, A., He, Y., So, M.K., Yeung, L.W.Y., Leung, H.W., Giesy, J.P., Lam, P.K.S., Martin, M., Richardson, B.J. 2007. The occurrence of selected antibiotics in Hong Kong coastal waters. Mar. Pollut. Bull., 54(8), 1287-1293.

Guo, X.S., Liu, J.X., Xiao, B.Y. 2013. Bioelectrochemical enhancement of hydrogen and methane production from the anaerobic digestion of sewage sludge in single-chamber membrane-free microbial electrolysis cells. Int. J. Hydrogen Energy, 38(3), 13421347.

Hamid, H., Eskicioglu, C. 2012. Fate of estrogenic hormones in wastewater and sludge treatment: A review of properties and analytical detection techniques in sludge matrix. Water Res., 46(18), 5813-5833.

He, L.Y., Ying, G.G., Liu, Y.S., Su, H.C., Chen, J., Liu, S.S., Zhao, J.L. 2016. Discharge of swine wastes risks water quality and food safety: Antibiotics and antibiotic resistance genes from swine sources to the receiving environments. Environ. Int., 92-93, 210219.

Heuer, H., Focks, A., Lamshöft, M., Smalla, K., Matthies, M., Spiteller, M. 2008. Fate of sulfadiazine administered to pigs and its quantitative effect on the dynamics of 
1360

1361

1362

1363

1364

1365

1366

1367

1368

1369

1370

1371

1372

1373

1374

1375

1376

1377

1378

1379

1380

1381

1382

1383

1384

bacterial resistance genes in manure and manured soil. Soil Biol. Biochem., 40(7), 1892-1900.

Hong, P.-Y., Al-Jassim, N., Ansari, M.I., Mackie, R.I. 2013. Environmental and public health implications of water reuse: antibiotics, antibiotic resistant bacteria, and antibiotic resistance genes. Antibiotics, 2(3), 367-399.

Hsieh, C.Y., Liaw, E.T., Fan, K.M. 2015. Removal of veterinary antibiotics, alkylphenolic compounds, and estrogens from the Wuluo constructed wetland in southern Taiwan. $J$. Environ. Sci. Health. A., 50(2), 151-60.

Hsu, J.T., Chen, C.Y., Young, C.W., Chao, W.L., Li, M.H., Liu, Y.H., Lin, C.M., Ying, C.W. 2014. Prevalence of sulfonamide-resistant bacteria, resistance genes and integronassociated horizontal gene transfer in natural water bodies and soils adjacent to a swine feedlot in northern Taiwan. J. Hazard. Mater., 277, 34-43.

Hu, D., Xu, J., Chen, Z., Wu, P., Wang, Z., Wang, P., Xiao, T., Su, H., Li, X., Wang, H., Zhang, Y. 2017. Performance of a pilot split-type anaerobic membrane bioreactor (AnMBR) treating antibiotics solvent wastewater at low temperatures. Chem. Eng. J., 325, 502-512.

Hu, D.X., Tian, Y., Wang, Z.J., Wu, P., Wang, P., Chen, Z.B., Cui, Y.B., Ge, H. 2016. The operational efficiency of a novel AnMBR treating antibiotic solvent wastewater in start-up stage. J. Water Reuse Desal., 7(3), 326-337.

Huang, L., Guo, R., Liang, J., Ma, B., Liao, X., Wu, Y. 2014a. Effect of Two Different Sulfamethazine Addition Methods on Psychrophilic Anaerobic Digestion of Swine Wastewater. Asian J. Chem., 26(2), 411.

Huang, L., Wen, X., Wang, Y., Zou, Y.D., Ma, B., Liao, X.D., Liang, J.B., Wu, Y.B. 2014b. Effect of the chlortetracycline addition method on methane production from the anaerobic digestion of swine wastewater. J. Environ. Sci. (China), 26(10), 2001-2006. 
Huang, M.H., Tian, S.X., Chen, D.H., Zhang, W., Wu, J., Chen, L. 2012. Removal of sulfamethazine antibiotics by aerobic sludge and an isolated Achromobacter sp. S-3. J. Environ. Sci. (China), 24(9), 1594-1599.

Huang, X., Liu, C., Li, K., Su, J., Zhu, G., Liu, L. 2015. Performance of vertical up-flow constructed wetlands on swine wastewater containing tetracyclines and tet genes. Water Res., 70, 109-117.

Huang, X., Zheng, J.L., Liu, C.X., Liu, L., Liu, Y.H., Fan, H.Y. 2017. Removal of antibiotics and resistance genes from swine wastewater using vertical flow constructed wetlands: Effect of hydraulic flow direction and substrate type. Chem. Eng. J., 308, 692-699.

Hussain, S.A., Prasher, S.O. 2011. Understanding the sorption of ionophoric pharmaceuticals in a treatment wetland. Wetlands, 31(3), 563-571.

Isabelle, M., Villemur, R., Juteau, P., Lépine, F. 2011. Isolation of estrogen-degrading bacteria from an activated sludge bioreactor treating swine waste, including a strain that converts estrone to $\beta$-estradiol. Can. J. Microbiol., 57(7), 559-568.

Johnson, A.C., Williams, R.J., Matthiessen, P. 2006. The potential steroid hormone contribution of farm animals to freshwaters, the United Kingdom as a case study. Sci. Total Environ., 362(1-3), 166-178.

Joo, H.S., Hirai, M., Shoda, M. 2006. Piggery wastewater treatment using Alcaligenes faecalis strain No. 4 with heterotrophic nitrification and aerobic denitrification. Water Res., 40(16), 3029-3036.

Joss, A., Andersen, H., Ternes, T., Richle, P.R., Siegrist, H. 2004. Removal of estrogens in municipal wastewater treatment under aerobic and anaerobic conditions: consequences for plant optimization. Environ. Sci. Technol., 38(11), 3047-3055. 
Kara, F., Gurakan, G., Sanin, F. 2008. Monovalent cations and their influence on activated sludge floc chemistry, structure, and physical characteristics. Biotechnol. Bioeng., $100(2), 231-239$.

Kemper, N. 2008. Veterinary antibiotics in the aquatic and terrestrial environment. Ecol. Indicators, 8(1), 1-13.

Khunjar, W., Mackintosh, S., Skotnicka-Pitak, J., Baik, S., Aga, D., Love, N. 2011. Elucidating the relative roles of ammonia oxidizing and heterotrophic bacteria during the biotransformation of $17 \alpha$-ethinylestradiol and trimethoprim. Environ. Sci. Technol., 45(8), 3605-3612.

Kim, H., Hong, Y., Park, J.-e., Sharma, V.K., Cho, S.-i. 2013. Sulfonamides and tetracyclines in livestock wastewater. Chemosphere, 91(7), 888-894.

Kim, H.S., Choung, Y.-K., Ahn, S., Oh, H.S. 2008. Enhancing nitrogen removal of piggery wastewater by membrane bioreactor combined with nitrification reactor. Desalination, 223(1-3), 194-204.

Kim, S., Eichhorn, P., Jensen, J.N., Weber, A.S., Aga, D.S. 2005. Removal of antibiotics in wastewater: Effect of hydraulic and solid retention times on the fate of tetracycline in the activated sludge process. Environ. Sci. Technol., 39(15), 5816-5823.

Kim, W., Shin, S.G., Cho, K., Lee, C., Hwang, S. 2012. Performance of methanogenic reactors in temperature phased two-stage anaerobic digestion of swine wastewater. $J$. Biosci. Bioeng., 114(6), 635-639.

Klomjek, P. 2016. Swine wastewater treatment using vertical subsurface flow constructed wetland planted with Napier grass. Sustain. Environ. Res., 26(5), 217-223.

Koike, S., Krapac, I., Oliver, H., Yannarell, A., Chee-Sanford, J., Aminov, R., Mackie, R. 2007. Monitoring and source tracking of tetracycline resistance genes in lagoons and 
groundwater adjacent to swine production facilities over a 3-year period. Appl. Environ. Microbiol., 73(15), 4813-4823.

Kolz, A., Moorman, T., Ong, S., Scoggin, K., Douglass, E. 2005. Degradation and metabolite production of tylosin in anaerobic and aerobic swine-manure lagoons. Water Environ. Res., 77(1), 49-56.

Kornboonraksa, T., Lee, H.S., Lee, S.H., Chiemchaisri, C. 2009. Application of chemical precipitation and membrane bioreactor hybrid process for piggery wastewater treatment. Bioresour. Technol., 100(6), 1963-1968.

Koyuncu, I., Arikan, O.A., Wiesner, M.R., Rice, C. 2008. Removal of hormones and antibiotics by nanofiltration membranes. J. Membr. Sci., 309(1-2), 94-101.

Lahnsteiner, F., Berger, B., Kletzl, M., Weismann, T. 2006. Effect of 17ß-estradiol on gamete quality and maturation in two salmonid species. Aquat. Toxicol., 79(2), 124-131.

Lange, I.G., Daxenberger, A., Schiffer, B., Witters, H., Ibarreta, D., Meyer, H.H.D. 2002. Sex hormones originating from different livestock production systems: fate and potential disrupting activity in the environment. Anal. Chim. Acta, 473(1-2), 27-37.

Leavey-Roback, S.L., Krasner, S.W., Suffet, I.H. 2016. Veterinary antibiotics used in animal agriculture as NDMA precursors. Chemosphere, 164, 330-338.

Li, B., Zhang, T. 2010. Biodegradation and adsorption of antibiotics in the activated sludge process. Environ. Sci. Technol., 44(9), 3468-3473.

Li, J., Meng, J., Li, J., Wang, C., Deng, K., Sun, K., Buelna, G. 2016. The effect and biological mechanism of COD/TN ratio on nitrogen removal in a novel upflow microaerobic sludge reactor treating manure-free piggery wastewater. Bioresour. Technol., 209, 360-368.

Li, J., Zhang, H. 2016. Adsorption-desorption of oxytetracycline on marine sediments: Kinetics and influencing factors. Chemosphere, 164, 156-163. 
Li, Y.F., Zhu, G.B., Ng, W.J., Tan, S.K. 2014. A review on removing pharmaceutical contaminants from wastewater by constructed wetlands: Design, performance and mechanism. Sci. Total Environ., 468-469, 908-932.

Li, Y.M., Zeng, Q.L., Yang, S.J. 2011. Removal and fate of estrogens in an anaerobic-anoxicoxic activated sludge system. Water Sci. Technol., 63(1), 51-56.

Lim, S.J. 2008. Swine wastewater treatment by the static granular bed reactor. Iowa State University.

Liu, L., Liu, C., Zheng, J., Huang, X., Wang, Z., Liu, Y., Zhu, G. 2013. Elimination of veterinary antibiotics and antibiotic resistance genes from swine wastewater in the vertical flow constructed wetlands. Chemosphere, 91(8), 1088-1093.

Liu, L., Liu, Y.-h., Wang, Z., Liu, C.-X., Huang, X., Zhu, G.-f. 2014. Behavior of tetracycline and sulfamethazine with corresponding resistance genes from swine wastewater in pilot-scale constructed wetlands. J. Hazard. Mater., 278, 304-310.

Liu, R., Chen, L.J., Song, X.Y., Wei, D., Zheng, W., Qiu, S.K., Zhao, Y. 2016. Treatment of digested piggery wastewater with a membrane bioreactor. Environ. En.g Mana.g J. 15(10).

Liu, S., Ying, G.G., Zhou, L.J., Zhang, R.Q., Chen, Z.F., Lai, H.J. 2012. Steroids in a typical swine farm and their release into the environment. Water Res., 46(12), 3754-3768.

Liu, S.S., Ying, G.G., Liu, Y.S., Yang, Y.Y., He, L.Y., Chen, J., Liu, W.R., Zhao, J.L. 2015a. Occurrence and removal of progestagens in two representative swine farms: Effectiveness of lagoon and digester treatment. Water Res., 77, 146-154.

Liu, Z.H., Kanjo, Y., Mizutani, S. 2009. Removal mechanisms for endocrine disrupting compounds (EDCs) in wastewater treatment-physical means, biodegradation, and chemical advanced oxidation: a review. Sci. Total Environ., 407(2), 731-748. 
Liu, Z.H., Lu, G.N., Yin, H., Dang, Z., Rittmann, B. 2015b. Removal of natural estrogens and their conjugates in municipal wastewater treatment plants: a critical review. Environ. Sci. Technol., 49(9), 5288-5300.

Lo, K., Liao, P., Gao, Y. 1994. Anaerobic treatment of swine wastewater using hybrid UASB reactors. Bioresour. Technol., 47(2), 153-157.

Lou, Y.Y., Ye, Z.L., Chen, S.H., Ye, X., Deng, Y.J., Zhang, J.Q. 2017. Sorption behavior of tetracyclines on suspended organic matters originating from swine wastewater. $J$. Environ. Sci.

Lu, M.Q., Niu, X.J., Liu, W., Zhang, J., Wang, J., Yang, J., Wang, W.Q., Yang, Z.Q. 2016. Biogas generation in anaerobic wastewater treatment under tetracycline antibiotic pressure. Sci. Rep., 6.

Luo, Y., Xu, L., Rysz, M., Wang, Y., Zhang, H., Alvarez, P.J. 2011. Occurrence and transport of tetracycline, sulfonamide, quinolone, and macrolide antibiotics in the Haihe River Basin, China. Environ. Sci. Technol., 45(5), 1827-1833.

Luo, Y.L., Guo, W.S., Ngo, H.H., Nghiem, L.D., Hai, F.I., Zhang, J., Liang, S., Wang, X.C. 2014. A review on the occurrence of micropollutants in the aquatic environment and their fate and removal during wastewater treatment. Sci. Total Environ., 473-474, 619-641.

Malintan, N.T., Mohd, M.A. 2006. Determination of sulfonamides in selected Malaysian swine wastewater by high-performance liquid chromatography. J. Chromatogr., 1127(1), 154-160.

Massé, D., Lu, D., Masse, L., Droste, R. 2000. Effect of antibiotics on psychrophilic anaerobic digestion of swine manure slurry in sequencing batch reactors. Bioresour. Technol., 75(3), 205-211. 
1505 Massé, D.I., Saady, N.M.C., Gilbert, Y. 2014. Potential of biological processes to eliminate 1506 antibiotics in livestock manure: an overview. Animals, 4(2), 146-163.

1507 Matamoros, V., García, J., Bayona, J.M. 2008. Organic micropollutant removal in a full-scale 1508 surface flow constructed wetland fed with secondary effluent. Water Res., 42(3), 653$1509 \quad 660$.

1510 Meng, J., Li, J., Li, J., Antwi, P., Deng, K., Wang, C., Buelna, G. 2015. Nitrogen removal 1511 from low COD/TN ratio manure-free piggery wastewater within an upflow 1512 1513 1514 microaerobic sludge reactor. Bioresour. Technol., 198, 884-890.

Migliore, L., Cozzolino, S., Fiori, M. 2003. Phytotoxicity to and uptake of enrofloxacin in crop plants. Chemosphere, 52(7), 1233-1244.

Mihciokur, H., Oguz, M. 2016. Removal of oxytetracycline and determining its biosorption properties on aerobic granular sludge. Environ. Toxicol. Pharmacol., 46, 174-182.

Mitchell, S.M., Ullman, J.L., Teel, A.L., Watts, R.J., Frear, C. 2013. The effects of the antibiotics ampicillin, florfenicol, sulfamethazine, and tylosin on biogas production and their degradation efficiency during anaerobic digestion. Bioresour. Technol., 149, 244-252.

Mohring, S.A., Strzysch, I., Fernandes, M.R., Kiffmeyer, T.K., Tuerk, J., Hamscher, G. 2009. Degradation and elimination of various sulfonamides during anaerobic fermentation: a promising step on the way to sustainable pharmacy? Environ. Sci. Technol., 43(7), $2569-2574$.

Montes, N., Otero, M., Coimbra, R.N., Mendez, R., Martin-Villacorta, J. 2015. Removal of tetracyclines from swine manure at full-scale activated sludge treatment plants. Environ. Technol., 36(15), 1966-1973. 
Müller, E., Schüssler, W., Horn, H., Lemmer, H. 2013. Aerobic biodegradation of the sulfonamide antibiotic sulfamethoxazole by activated sludge applied as co-substrate and sole carbon and nitrogen source. Chemosphere, 92(8), 969-978.

Munir, M., Wong, K., Xagoraraki, I. 2011. Release of antibiotic resistant bacteria and genes in the effluent and biosolids of five wastewater utilities in Michigan. Water Res., 45(2), 681-693.

Nguyen, L.N., Hai, F.I., Kang, J., Price, W.E., Nghiem, L.D. 2013. Removal of emerging trace organic contaminants by MBR-based hybrid treatment processes. Int. Biodeterior. Biodegrad., 85, 474-482.

Oliveira, G., Santos-Neto, A., Zaiat, M. 2016. Evaluation of sulfamethazine sorption and biodegradation by anaerobic granular sludge using batch experiments. Bioprocess Biosyst. Eng., 39(1), 115-124.

Onesios, K.M., Jim, T.Y., Bouwer, E.J. 2009. Biodegradation and removal of pharmaceuticals and personal care products in treatment systems: a review. Biodegradation, 20(4), 441-466.

Pan, X., Qiang, Z.M., Ben, W.W., Chen, M.X. 2011. Simultaneous determination of three classes of antibiotics in the suspended solids of swine wastewater by ultrasonic extraction, solid-phase extraction and liquid chromatography-mass spectrometry. J. Environ. Sci., 23(10), 1729-1737.

Papaevangelou, V.A., Gikas, G.D., Tsihrintzis, V.A., Antonopoulou, M., Konstantinou, I.K. 2016. Removal of endocrine disrupting chemicals in HSF and VF pilot-scale constructed wetlands. Chem. Eng. J., 294, 146-156.

Pauwels, B., Wille, K., Noppe, H., De Brabander, H., Van de Wiele, T., Verstraete, W., Boon, N. 2008. 17 $\alpha$-ethinylestradiol cometabolism by bacteria degrading estrone, $17 \beta$ estradiol and estriol. Biodegradation, 19(5), 683-693. 
1553 Peak, N., Knapp, C.W., Yang, R.K., Hanfelt, M.M., Smith, M.S., Aga, D.S., Graham, D.W. 1554 2007. Abundance of six tetracycline resistance genes in wastewater lagoons at cattle 1555 feedlots with different antibiotic use strategies. Environ. Microbiol., 9(1), 143-151. 1556 Prado, N., Ochoa, J., Amrane, A. 2009a. Biodegradation and biosorption of tetracycline and 1557 tylosin antibiotics in activated sludge system. Process Biochem., 44(11), 1302-1306. 1558 Prado, N., Ochoa, J., Amrane, A. 2009b. Biodegradation by activated sludge and toxicity of 1559 1560 1561 tetracycline into a semi-industrial membrane bioreactor. Bioresour. Technol., 100(15), $3769-3774$.

Qiang, Z., Macauley, J.J., Mormile, M.R., Surampalli, R., Adams, C.D. 2006. Treatment of antibiotics and antibiotic resistant bacteria in swine wastewater with free chlorine. $J$. Agric. Food Chem., 54(21), 8144-8154.

Quintana, J.B., Weiss, S., Reemtsma, T. 2005. Pathways and metabolites of microbial degradation of selected acidic pharmaceutical and their occurrence in municipal wastewater treated by a membrane bioreactor. Water Res., 39(12), 2654-2664.

Raman, D.R., Williams, E.L., Layton, A.C., Burns, R.T., Easter, J.P., Daugherty, A.S., Mullen, M.D., Sayler, G.S. 2004. Estrogen content of dairy and swine wastes. Environ. Sci. Technol., 38(13), 3567-3573.

Remy, M., Potier, V., Temmink, H., Rulkens, W. 2010. Why low powdered activated carbon addition reduces membrane fouling in MBRs. Water Res., 44(3), 861-867.

Remy, M., Temmink, H., van den Brink, P., Rulkens, W. 2011. Low powdered activated carbon concentrations to improve MBR sludge filterability at high salinity and low temperature. Desalination, 276(1-3), 403-407.

Remy, M., van der Marel, P., Zwijnenburg, A., Rulkens, W., Temmink, H. 2009. Low dose powdered activated carbon addition at high sludge retention times to reduce fouling in membrane bioreactors. Water Res., 43(2), 345-350. 
1578 Ren, Y.-X., Nakano, K., Nomura, M., Chiba, N., Nishimura, O. 2007. A thermodynamic

1579

1580

1581

1582 analysis on adsorption of estrogens in activated sludge process. Water Res., 41(11), $2341-2348$.

Rizzo, L., Manaia, C., Merlin, C., Schwartz, T., Dagot, C., Ploy, M., Michael, I., FattaKassinos, D. 2013. Urban wastewater treatment plants as hotspots for antibiotic resistant bacteria and genes spread into the environment: a review. Sci. Total Environ., 447, 345-360.

Sahar, E., Ernst, M., Godehardt, M., Hein, A., Herr, J., Kazner, C., Melin, T., Cikurel, H., Aharoni, A., Messalem, R. 2011a. Comparison of two treatments for the removal of selected organic micropollutants and bulk organic matter: conventional activated sludge followed by ultrafiltration versus membrane bioreactor. Water Sci. Technol., 63(4), 733-740.

Sahar, E., Messalem, R., Cikurel, H., Aharoni, A., Brenner, A., Godehardt, M., Jekel, M., Ernst, M. 2011b. Fate of antibiotics in activated sludge followed by ultrafiltration (CAS-UF) and in a membrane bioreactor (MBR). Water Res., 45(16), 4827-4836.

Sakar, S., Yetilmezsoy, K., Kocak, E. 2009. Anaerobic digestion technology in poultry and livestock waste treatment —a literature review. Waste Manage. Res., 27(1), 3-18.

Sanchez Huerta, C. 2016. Removal and degradation pathways of sulfamethoxazole present in synthetic municipal wastewater via an anaerobic membrane bioreactor. $\mathrm{PhD}$ diss.

Sarmah, A., Northcott, G., Leusch, F., Tremblay, L. 2006a. A survey of endocrine disrupting chemicals (EDCs) in municipal sewage and animal waste effluents in the Waikato region of New Zealand. Sci. Total Environ., 355(1), 135-144.

Sarmah, A.K., Meyer, M.T., Boxall, A.B. 2006b. A global perspective on the use, sales, exposure pathways, occurrence, fate and effects of veterinary antibiotics (VAs) in the environment. Chemosphere, 65(5), 725-759. 
Scholz, M., Lee, B.h. 2005. Constructed wetlands: a review. Int. J. Environ. Stud., 62(4), 421-447.

Shappell, N.W., Billey, L.O., Forbes, D., Matheny, T.A., Poach, M.E., Reddy, G.B., Hunt, P.G. 2007. Estrogenic activity and steroid hormones in swine wastewater through a lagoon constructed-wetland system. Environ. Sci. Technol., 41(2), 444-450.

Sharma, V.K., Johnson, N., Cizmas, L., McDonald, T.J., Kim, H. 2016. A review of the influence of treatment strategies on antibiotic resistant bacteria and antibiotic resistance genes. Chemosphere, 150, 702-714.

Shi, J., Fujisawa, S., Nakai, S., Hosomi, M. 2004. Biodegradation of natural and synthetic estrogens by nitrifying activated sludge and ammonia-oxidizing bacterium Nitrosomonas europaea. Water Res., 38(9), 2323-2330.

Shi, J.H., Chen, Q.C., Liu, X.W., Zhan, X.M., Li, J., Li, Z.B. 2013. Sludge/water partition and biochemical transformation of estrone and $17 \beta$-estradiol in a pilot-scale step-feed anoxic/oxic wastewater treatment system. Biochem. Eng. J., 74, 107-114.

Shi, Y.J., Wang, X.H., Qi, Z., Diao, M.H., Gao, M.M., Xing, S.F., Wang, S.G., Zhao, X.C. 2011. Sorption and biodegradation of tetracycline by nitrifying granules and the toxicity of tetracycline on granules. J. Hazard. Mater., 191(1-3), 103-109.

Silva, C.P., Otero, M., Esteves, V. 2012. Processes for the elimination of estrogenic steroid hormones from water: a review. Environ. Pollut., 165, 38-58.

Sombatsompop, K., Songpim, A., Reabroi, S., Inkong-ngam, P. 2011. A comparative study of sequencing batch reactor and movingbed sequencing batch reactor for piggery wastewater treatment. Maejo Int. J. Sci. Technol., 5(2).

Song, H.L., Nakano, K., Taniguchi, T., Nomura, M., Nishimura, O. 2009. Estrogen removal from treated municipal effluent in small-scale constructed wetland with different depth. Bioresour. Technol., 100(12), 2945-2951. 
Song, W., Wang, X., Gu, J., Zhang, S., Yin, Y., Li, Y., Qian, X., Sun, W. 2017a. Effects of different swine manure to wheat straw ratios on antibiotic resistance genes and the microbial community structure during anaerobic digestion. Bioresour. Technol., 231, $1-8$.

Song, X., Liu, R., Chen, L., Dong, B., Kawagishi, T. 2017b. Advantages of intermittently aerated SBR over conventional SBR on nitrogen removal for the treatment of digested piggery wastewater. Front. Environ. Sci. Eng., 11(3), 13.

Song, X.Y., Liu, R., Chen, L.J., Kawagishi, T. 2017c. Comparative experiment on treating digested piggery wastewater with a biofilm MBR and conventional MBR: simultaneous removal of nitrogen and antibiotics. Front. Environ. Sci. Eng., 11(2), 11.

Speltini, A., Sturini, M., Maraschi, F., Profumo, A., Albini, A. 2011. Analytical methods for the determination of fluoroquinolones in solid environmental matrices. TrAC, Trends Anal. Chem., 30(8), 1337-1350.

Stackelberg, P.E., Gibs, J., Furlong, E.T., Meyer, M.T., Zaugg, S.D., Lippincott, R.L. 2007. Efficiency of conventional drinking-water-treatment processes in removal of pharmaceuticals and other organic compounds. Sci. Total Environ., 377(2), 255-272.

Stone, J.J., Clay, S.A., Zhu, Z.W., Wong, K.L., Porath, L.R., Spellman, G.M. 2009. Effect of antimicrobial compounds tylosin and chlortetracycline during batch anaerobic swine manure digestion. Water Res., 43(18), 4740-4750.

Suárez, S., Carballa, M., Omil, F., Lema, J.M. 2008. How are pharmaceutical and personal care products (PPCPs) removed from urban wastewaters? Rev. Environ. Sci. Bio., 7(2), $125-138$.

Sui, Q., Zhang, J., Chen, M., Tong, J., Wang, R., Wei, Y. 2016. Distribution of antibiotic resistance genes (ARGs) in anaerobic digestion and land application of swine wastewater. Environ. Pollut., 213, 751-759. 
Sui, Q.W., Liu, C., Dong, H.M., Zhu, Z.P. 2014. Effect of ammonium nitrogen concentration on the ammonia-oxidizing bacteria community in a membrane bioreactor for the treatment of anaerobically digested swine wastewater. J. Biosci. Bioeng., 118(3), 277283.

Suto, R., Ishimoto, C., Chikyu, M., Aihara, Y., Matsumoto, T., Uenishi, H., Yasuda, T., Fukumoto, Y., Waki, M. 2017. Anammox biofilm in activated sludge swine wastewater treatment plants. Chemosphere, 167, 300-307.

Suzuki, K., Waki, M., Yasuda, T., Fukumoto, Y., Kuroda, K., Sakai, T., Suzuki, N., Suzuki, R., Matsuba, K. 2010. Distribution of phosphorus, copper and zinc in activated sludge treatment process of swine wastewater. Bioresour. Technol., 101(23), 9399-9404.

Suzuki, Y., Kubota, A., Furukawa, T., Sugamoto, K., Asano, Y., Takahashi, H., Sekito, T., Dote, Y., Sugimoto, Y. 2009. Residual of $17 \beta$-estradiol in digestion liquid generated from a biogas plant using livestock waste. J. Hazard. Mater., 165(1-3), 677-682.

Tang, X.J., Hashmi, M.Z., Zhang, H., Qian, M.T., Yu, C.n., Shen, C.F., Qin, Z.H., Huang, R.L., Qiao, J.N., Chen, Y.X. 2013. A preliminary study on the occurrence and dissipation of estrogen in livestock wastewater. Bull. Environ. Contam. Toxicol., 90(4), 391-396.

Tasho, R.P., Cho, J.Y. 2016. Veterinary antibiotics in animal waste, its distribution in soil and uptake by plants: a review. Sci. Total Environ., 563, 366-376.

Ternes, T.A., Stumpf, M., Mueller, J., Haberer, K., Wilken, R.D., Servos, M. 1999. Behavior and occurrence of estrogens in municipal sewage treatment plants-I. Investigations in Germany, Canada and Brazil. Sci. Total Environ., 225(1), 81-90.

Tijani, J.O., Fatoba, O.O., Petrik, L.F. 2013. A review of pharmaceuticals and endocrinedisrupting compounds: sources, effects, removal, and detections. Water, Air, Soil Pollut., 224(11), 1770. 
1678 Tiwari, B., Sellamuthu, B., Ouarda, Y., Drogui, P., Tyagi, R.D., Buelna, G. 2016. Review on

1679

1680

1681

1682

1683

1684

1685

1686

1687

1688

1689

1690

1691

1692

1693

1694

1695

1696

1697

1698

1699

1700

1701

1702

Fate and Mechanism of removal of pharmaceutical pollutants from wastewater using biological approach. Bioresour. Technol.

Tiwari, B., Sellamuthu, B., Ouarda, Y., Drogui, P., Tyagi, R.D., Buelna, G. 2017. Review on fate and mechanism of removal of pharmaceutical pollutants from wastewater using biological approach. Bioresour. Technol., 224, 1-12.

Tong, L., Li, P., Wang, Y.X., Zhu, K.Z. 2009. Analysis of veterinary antibiotic residues in swine wastewater and environmental water samples using optimized SPE-LC/MS/MS. Chemosphere, 74(8), 1090-1097.

Tong, Z., Liu, Y., Hu, Z., Yuan, S. 2012. Anaerobic digestion of animal manure contaminated by tetracyclines. Huan jing ke хие, 33(3), 1028-1032.

Töre, G.Y., Meriç, S., Lofrano, G., De Feo, G. 2012. Removal of Trace Pollutants from Wastewater in Constructed Wetlands. in: Emerging Compounds Removal from Wastewater, Springer, pp. 39-58.

Tran, N.H., Chen, H.J., Reinhard, M., Mao, F.J., Gin, K.Y.H. 2016. Occurrence and removal of multiple classes of antibiotics and antimicrobial agents in biological wastewater treatment processes. Water Res., 104, 461-472.

Truu, M., Juhanson, J., Truu, J. 2009. Microbial biomass, activity and community composition in constructed wetlands. Sci. Total Environ., 407(13), 3958-3971.

Uno, K., Aoki, T., Kleechaya, W., Tanasomwang, V., Ruangpan, L. 2006. Pharmacokinetics of oxytetracycline in black tiger shrimp, Penaeus monodon, and the effect of cooking on the residues. Aquaculture, 254(1), 24-31.

Varel, V., Wells, J., Shelver, W., Rice, C., Armstrong, D., Parker, D. 2012. Effect of anaerobic digestion temperature on odour, coliforms and chlortetracycline in swine manure or monensin in cattle manure. J. Appl. Microbiol., 112(4), 705-715. 
1703 Vieno, N.M., Härkki, H., Tuhkanen, T., Kronberg, L. 2007. Occurrence of pharmaceuticals in

1704

1705

1706

1707

1708

1709

1710

1711

1712

1713

1714

1715

1716

1717

1718

1719

1720

1721

1722

1723

1724

1725

1726 river water and their elimination in a pilot-scale drinking water treatment plant. Environ. Sci. Technol., 41(14), 5077-5084.

Vymazal, J. 2013. The use of hybrid constructed wetlands for wastewater treatment with special attention to nitrogen removal: a review of a recent development. Water Res., 47(14), 4795-4811

Wang, J., Ben, W., Yang, M., Zhang, Y., Qiang, Z. 2016. Dissemination of veterinary antibiotics and corresponding resistance genes from a concentrated swine feedlot along the waste treatment paths. Environ. Int., 92, 317-323.

Wang, J.L., Wang, S.Z. 2016. Removal of pharmaceuticals and personal care products (PPCPs) from wastewater: a review. J. Environ. Manage., 182, 620-640.

Wang, R., Chen, M., Feng, F., Zhang, J., Sui, Q., Tong, J., Wei, Y., Wei, D. 2017. Effects of chlortetracycline and copper on tetracyclines and copper resistance genes and microbial community during swine manure anaerobic digestion. Bioresour. Technol., 238, 57-69.

Wei, D., Wan, M., Liu, R., Wang, G.R., Zhang, X.D., Wen, X.G., Zhao, Y., Chen, L.J. 2014. Study on the quality of digested piggery wastewater in large-scale farms in Jiaxing. Huan Jing Ke Xue, 35(7), 2650-2657.

Wei, R.C., Ge, F., Huang, S.Y., Chen, M., Wang, R. 2011. Occurrence of veterinary antibiotics in animal wastewater and surface water around farms in Jiangsu Province, China. Chemosphere, 82(10), 1408-1414.

Widyasari Mehta, A., Hartung, S., Kreuzig, R. 2016a. From the application of antibiotics to antibiotic residues in liquid manures and digestates: a screening study in one European center of conventional pig husbandry. J. Environ. Manage., 177, 129-137. 
Widyasari Mehta, A., Suwito, H.R.K.A., Kreuzig, R. 2016b. Laboratory testing on the removal of the veterinary antibiotic doxycycline during long-term liquid pig manure and digestate storage. Chemosphere, 149, 154-160.

Wijekoon, K.C., Hai, F.I., Kang, J.G., Price, W.E., Guo, W.S., Ngo, H.H., Nghiem, L.D. 2013. The fate of pharmaceuticals, steroid hormones, phytoestrogens, UV-filters and pesticides during MBR treatment. Bioresour. Technol., 144, 247-254.

Wu, H.M., Zhang, J., Ngo, H.H., Guo, W.S., Hu, Z., Liang, S., Fan, J.1., Liu, H. 2015. A review on the sustainability of constructed wetlands for wastewater treatment: Design and operation. Bioresour. Technol., 175, 594-601.

Wu, Y.B., Huang, L., Wang, X.Q., Ma, B.H., Liao, X.D., Chen, G.X., Peng, P.C. 2011. Effects of tylocin on room anaerobic digestion of swine sewage. CASE, 2011(14).

Xian, Q.M., Hu, L.X., Chen, H.C., Chang, Z.Z., Zou, H.X. 2010. Removal of nutrients and veterinary antibiotics from swine wastewater by a constructed macrophyte floating bed system. J. Environ. Manage., 91(12), 2657-2661.

Xue, W.C., Wu, C.Y., Xiao, K., Huang, X., Zhou, H.D., Tsuno, H., Tanaka, H. 2010. Elimination and fate of selected micro-organic pollutants in a full-scale anaerobic/anoxic/aerobic process combined with membrane bioreactor for municipal wastewater reclamation. Water Res., 44(20), 5999-6010.

Yamamoto, H., Morita, M., Liljestrand, H. 2003. Estimated fate of selected endocrine disruptors in the aquatic environment and the biological treatment processes: sorption by dissolved organic matter and synthetic membrane vesicles. Fourth specialized conference on assessment and control of hazardous substances in water. International Water Association (IWA), Aachen, Germany. pp. 14-17. 
1750 Yang, S.F., Lin, C.F., Yu C. L., A., Andy Hong, P.K. 2011. Sorption and biodegradation of 1751 sulfonamide antibiotics by activated sludge: Experimental assessment using batch 1752 data obtained under aerobic conditions. Water Res., 45(11), 3389-3397.

1753 Yang, S.F., Lin, C.F., Wu, C.J., Ng, K.K., Yu-Chen Lin, A., Andy Hong, P.-K. 2012. Fate of 1754 sulfonamide antibiotics in contact with activated sludge - Sorption and biodegradation. $1755 \quad$ Water Res., 46(4), 1301-1308.

1756 Yang, W., Cicek, N. 2008. Treatment of swine wastewater by submerged membrane 1757 1758 bioreactors with consideration of estrogenic activity removal. Desalination, 231(1-3),

1759 Yao, L.L., Wang, Y.X., Tong, L., Deng, Y., Li, Y.G., Gan, Y.Q., Guo, W., Dong, C.J., Duan, 1760 Y.H., Zhao, K. 2017. Occurrence and risk assessment of antibiotics in surface water 1761 and groundwater from different depths of aquifers: a case study at Jianghan Plain, 1762 central China. Ecotoxicol. Environ. Saf., 135, 236-242.

1763 Yi, T., Harper, W.F. 2007. The link between nitrification and biotransformation of $17 \alpha-$ 1764 ethinylestradiol. Environ. Sci. Technol., 41(12), 4311-4316.

1765 Zhang, D.Q., Tan, S.K., Gersberg, R.M., Sadreddini, S., Zhu, J.F., Tuan, N.A. 2011 a.

1766 Removal of pharmaceutical compounds in tropical constructed wetlands. Ecol. Eng., 1767 37(3), 460-464.

1768 Zhang, H., Shi, J.H., Liu, X.W., Zhan, X.M., Chen, Q.C. 2014. Occurrence and removal of 1769 free estrogens, conjugated estrogens, and bisphenol A in manure treatment facilities in $1770 \quad$ East China. Water Res., 58, 248-257.

1771 Zhang, L., Lee, Y.W., Jahng, D. 2011b. Anaerobic co-digestion of food waste and piggery 1772 wastewater: Focusing on the role of trace elements. Bioresour. Technol., 102(8), $1773 \quad 5048-5059$. 
1775

1776

1777

Zhang, S., Song, H.L., Yang, X.L., Huang, S., Dai, Z.Q., Li, H., Zhang, Y.Y. 2017. Dynamics of antibiotic resistance genes in microbial fuel cell-coupled constructed wetlands treating antibiotic-polluted water. Chemosphere, 178, 548-555.

Zhang, Z.J., Zhu, J., King, J., Li, W.H. 2006. A two-step fed SBR for treating swine manure. Process Biochem., 41(4), 892-900.

Zhao, C., Shao, Q., Ma, Z., Li, B., Zhao, X. 2016. Physical and chemical characterizations of corn stalk resulting from hydrogen peroxide presoaking prior to ammonia fiber expansion pretreatment. Ind. Crops Prod., 83, 86-93.

Zhao, J.W., Lin, W., Ma, X.H., Lu, Q.Y., Ma, X., Bian, G.H., Jiang, L.H. 2010. The protein kinase Hal5p is the high-copy suppressor of lithium-sensitive mutations of genes involved in the sporulation and meiosis as well as the ergosterol biosynthesis in Saccharomyces cerevisiae. Genomics, 95(5), 290-298.

Zheng, W., Li, X.L., Yates, S.R., Bradford, S.A. 2012. Anaerobic transformation kinetics and mechanism of steroid estrogenic hormones in dairy lagoon water. Environ. Sci. Technol., 46(10), 5471-5478.

Zheng, W., Zhang, Z.Y., Liu, R., Lei, Z.F. 2017. Removal of veterinary antibiotics from anaerobically digested swine wastewater using an intermittently aerated sequencing batch reactor. J. Environ. Sci..

Zheng, X.Y., He, Y.J., Chen, W., Wang, M.Y., Cao, S.L., Ni, M., Chen, Y. 2016. A comparative adsorption study: 17beta-estradiol onto aerobic granular sludge and activated sludge. Environ. Technol., 37(1), 136-44.

Zhi, W., Ji, G.D. 2012. Constructed wetlands, 1991-2011: a review of research development, current trends, and future directions. Sci. Total Environ., 441, 19-27. 
1797 Zhou, L.J., Ying, G.G., Liu, S., Zhao, J.L., Yang, B., Chen, Z.F., Lai, H.J. 2013. Occurrence

1798 and fate of eleven classes of antibiotics in two typical wastewater treatment plants in 1799 South China. Sci. Total Environ., 452, 365-376.

1800 Zhou, L.J., Ying, G.G., Zhao, J.L., Yang, J.F., Wang, L., Yang, B., Liu, S. 2011. Trends in 1801 the occurrence of human and veterinary antibiotics in the sediments of the Yellow 1802 River, Hai River and Liao River in northern China. Environ. Pollut., 159(7), 1877$1803 \quad 1885$.

1804 Zhou, L.J., Zhao, M., Feng, L., Wang, X., Xu, X.Y., Xia, S.Q. 2016. Performance and 1805 bacterial community structure of an anoxic/oxic membrane bioreactor treating 1806 anaerobically digested piggery wastewater. Desalination Water Treat., 57(59), 28581$1807 \quad 28591$.

1808 Zhu, Y.J., Wang, Y.Y., Jiang, X.X., Zhou, S., Wu, M., Pan, M., Chen, H. 2017. Microbial 1809 community compositional analysis for membrane bioreactor treating antibiotics 1810 containing wastewater. Chem. Eng. J., 325, 300-309. 